\title{
Botanical Modulation of Menopausal Symptoms: Mechanisms of Action?
}

Authors

Affiliation
Atieh Hajirahimkhan, Birgit M. Dietz, Judy L. Bolton

UIC/NIH Center for Botanical Dietary Supplements, Department of Medicinal Chemistry and Pharmacognosy, College of Pharmacy, University of Illinois at Chicago, Chicago, Illinois, USA

\section{Key words \\ - botanicals \\ - estrogen \\ - isoflavones \\ - menopause \\ - progesterone \\ - serotonin}

received July 20, 2012

revised Nov. 28, 2012

accepted January 4, 2013

\section{Bibliography}

Dol http://dx.doi.org/ 10.1055/s-0032-1328187

Published online February 13, 2013

Planta Med 2013; 79: 538-553

(c) Georg Thieme Verlag KC

Stuttgart · New York .

ISSN 0032-0943

\section{Correspondence}

\section{Prof. Dr. Judy Bolton}

Department of Medicinal Chemistry and Pharmacognosy

College of Pharmacy, University of Illinois at Chicago

833 South Wood St. M/C 781

Chicago IL 60612-7231

USA

Phone: + 13129965280

Fax: +13129967107

judy.bolton@uic.edu

\section{Abstract \\ $\nabla$}

Menopausal women suffer from a variety of symptoms, including hot flashes and night sweats, which can affect quality of life. Although it has been the treatment of choice for relieving these symptoms, hormone therapy has been associated with increased breast cancer risk leading many women to search for natural, efficacious, and safe alternatives such as botanical supplements. Data from clinical trials suggesting that botanicals have efficacy for menopausal symptom relief have been controversial, and several mechanisms of action have been proposed including estrogenic, progestogenic, and serotonergic pathways. Plant extracts with potential estrogenic activities include soy, red clover, kudzu, hops, licorice, rhubarb, yam, and chasteberry. Botanicals with reported progestogenic activities are red clover, hops, yam, and chasteberry. Serotonergic mechanisms have also been proposed since women taking antidepressants often report a reduction in hot flashes and night sweats. Black cohosh, kudzu, kava, licorice, and dong quai all either have reported 5-hydroxytryptamine receptor 7 ligands or inhibit serotonin reuptake, therefore have potential serotonergic activities. Understanding the mechanisms of action of these natural remedies used for women's health could lead to more effi-

\section{Introduction}

$\nabla$

Women potentially spend the last third of their lives in postmenopause, due to their increased life expectancy. Menopausal women suffer from a variety of symptoms, such as hot flashes, night sweats, mood swings, insomnia, vaginal dryness, in addition to long-term complications such as osteoporosis $[1,2]$. These symptoms arise primarily as a response to the drastic decline in circulating endogenous estrogens [3]. In order to relieve cacious formulations and to the isolation of active components which have the potential of becoming effective medications in the future.

\section{Abbreviations \\ $\nabla$}

AP-1: $\quad$ activator protein 1

$\mathrm{E}_{2}$ : $\quad 17 \beta$-estradiol

ER: estrogen receptor

ERE: estrogen responsive element

GPER: G-protein coupled estrogen receptor

GPR30: G-protein coupled estrogen receptor subtype 30

HT: hormone therapy

5-HT: 5-hydroxytryptamine (serotonin)

5-HT $:$ 5-hydroxytryptamine receptor 7

MAPKs: mitogen-activated protein kinases

PI3K: $\quad$ phosphatidylinositol 3-kinase

8-PN 8-prenylnaringenin

$\mathrm{P}_{4}$ : $\quad$ progesterone

PR: $\quad$ progesterone receptor

PRE: $\quad$ progesterone responsive element

SERT: $\quad$ serotonin transporter

SSRI: selective serotonin reuptake inhibitor

WHI: Women's Health Initiative menopausal symptoms, traditional HT (estrogen or estrogen plus progestin), was designed to supplement the hormones. However, the WHI demonstrated an increased risk of developing breast cancer associated with HT [4] leading women to search for natural alternatives such as botanical supplements $[5,6]$.

Botanicals, which are generally perceived as safe due to their natural origin, have a long history of use for female complaints, particularly in traditional Chinese medicine [7]. The fact that Asian 


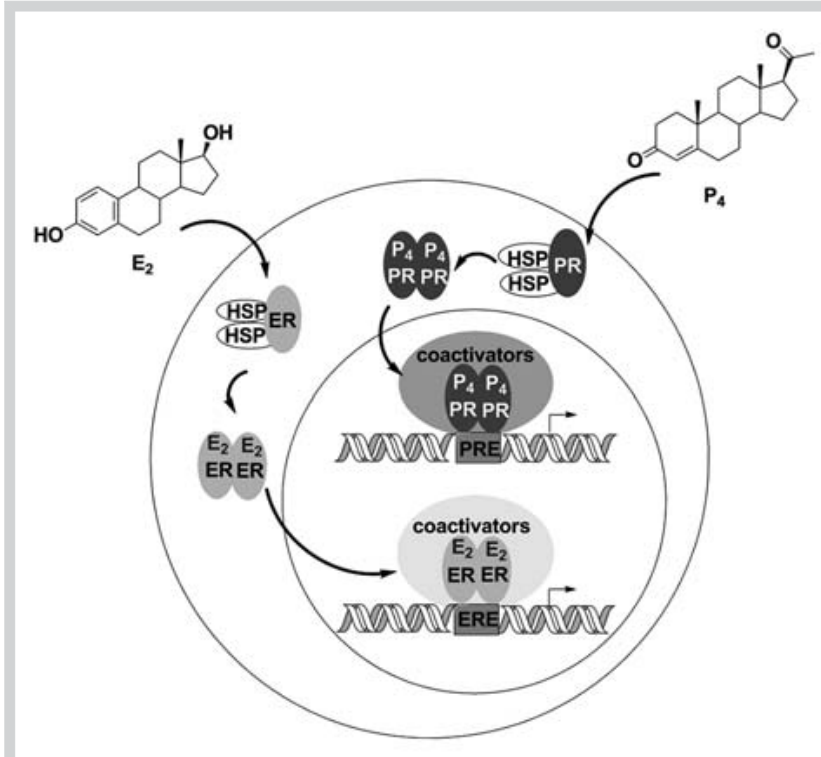

Fig. 1 Classical mechanisms of the estrogenic and progestogenic activities.

women have less frequent and severe hot flashes suggests that this effect could be associated with their flavonoid-rich diet and that botanicals with high flavonoid content could be effective in managing menopausal symptoms [8]. As a result, many women turn to botanical dietary supplements for alleviation of menopausal symptoms, specifically for the reduction of hot flashes [5, 6].

Botanical supplements could act through a number of different mechanisms including estrogenic, progestogenic, and/or serotonergic pathways ( Figs. 1 and 2) [9-13]. It is thought that botanicals with estrogenic activity might mimic the actions of estrogens. The importance of estrogen in homeostatic regulation of many cellular and biochemical events is well illustrated by the pathophysiological changes that occur with estrogen deficiency [14-17]. Endogenous estrogen (estradiol, $E_{2}$ ) is actively involved in the development of the mammary gland and uterus, in maintaining pregnancy and bone density, in protection from cardiovascular diseases, and in relieving menopausal symptoms [1619]. Estrogens mainly exert their biological effects through binding to ERs including ER $\alpha$ and ER $\beta$, followed by dimerization of ERs and interaction with EREs at the promoter of the estrogen responsive genes, thus activating transcription and generating estrogenic responses which are crucial for normal physiological functions ( Fig. 1) [20-22]. In humans around one-third of the genes that are regulated by ERs do not contain ERE-like sequences [22,23]. ERs can also tether to other transcription factors such as Fos and Jun that are directly bound to DNA through their respective responsive elements such as AP1 binding sites to regulate transcription of the related genes [22,23]. Estrogen also activates rapid signaling pathways such as MAPKs and PI3K pathways, which, in turn, can modulate transcription and proliferation $[22,24]$. Studies have revealed another type of ER, namely GPER or GPR30, that is involved in different signaling pathways $[25,26]$. It is also known that mechanisms of $E_{2}$ actions depend on the ligand, the cell type, and the receptor subtype [22,23]. It is believed that $\mathrm{ER} \alpha$ induction is responsible for the proliferative

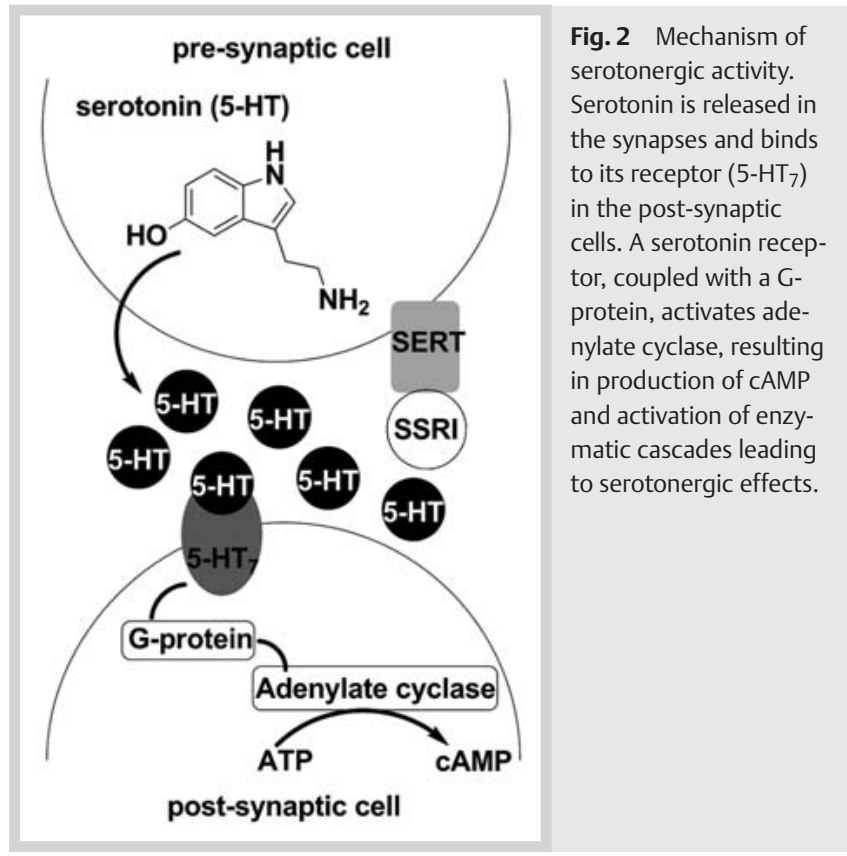

effects of estrogens, while ER $\beta$ activation balances the ER $\alpha$-dependent responses [27-29].

Botanicals and specifically their phytoestrogens, such as genistein and daidzein, preferentially bind and activate ER $\beta$, thus may exert a safe estrogenic activity $[15,30]$. However, the use of botanicals with only plant-derived estrogens in the absence of progestins might increase the risk of developing endometrial hyperplasia and cancer similar to conventional estrogen-alone HT [31, 32]. It is known that women with an intact uterus who take HT to treat estrogen-deficient menopausal symptoms must take a combination of estrogens and progestins, and the same is likely true for phytoestrogens and phytoprogestins. $\mathrm{P}_{4}$, the precursor of many steroid hormones, plays a crucial role in the normal physiology of the uterus, ovaries, mammary gland, cardiovascular system, bone, brain, and central nervous system [33]. Its biological function is mainly mediated through its binding to PRs, including PRA and PRB, followed by the receptor dimerization, translocation to the nucleus, and interaction with PREs, thus regulating transcription of downstream genes ( Fig. 1) [34]. Animal models partially suggest that PRA induction is protective in the uterus, while PRB induction might increase breast proliferation [35-37]. Botanicals containing natural progestins, which can activate progesterone-dependent pathways, in addition to estrogenic compounds are preferred.

Estrogen withdrawal during menopause results in the decline in the release of neurotransmitters, primarily norepinephrine and serotonin (5-HT), which will lead to a change in thermoregulation in the hypothalamus [38]. This effect ultimately results in frequent sweating and increased peripheral circulation as heatloss mechanisms generating hot flashes and night sweats. Increase in the amount of serotonin and activation of certain 5-HT receptors as well as inhibition of serotonin reuptake in synapses through the blocking of SERTs are possible approaches in preventing hot flashes ( Fig. 2). In order to avoid hormonal approaches, some women choose SSRIs to manage menopausal discomforts, particularly vasomotor symptoms [39]. However, there are also a number of undesirable outcomes such as sexual dys- 
Table 1 Estrogenic potency of phytoestrogens in competitive ER binding assay ${ }^{\mathrm{a}}$.

\begin{tabular}{|c|c|c|c|c|}
\hline \multirow[t]{2}{*}{ Compound $^{b}$} & \multirow[t]{2}{*}{ Plant } & \multirow[t]{2}{*}{ References } & \multicolumn{2}{|c|}{$\mathrm{IC}_{50}(\mu \mathrm{M})$ reported range ER binding } \\
\hline & & & ER $\alpha$ & ER $\beta$ \\
\hline $17 \beta$-estradiol $\left(\mathrm{E}_{2}\right)$ & - & {$[89,101,185]$} & $0.00001-0.003$ & $0.0014-0.0038$ \\
\hline Genistein & soy, red clover, kudzu & {$[50,101,185]$} & $0.59-1.145$ & $0.025-0.09$ \\
\hline Daidzein & soy, red clover, kudzu & {$[9,185,186]$} & $0.96-17$ & $0.1-1.20$ \\
\hline S-equol & soy, red clover, kudzu & {$[50,138,185]$} & $0.208-1.02$ & $0.016-0.11$ \\
\hline Kaempferol & red clover & {$[80,186]$} & 8.2 & $0.05-50$ \\
\hline Puerarin & kudzu & [187] & 0.87 & $N^{c}$ \\
\hline Miroestrol & kudzu & [89] & 0.0003 & $N^{c}$ \\
\hline 8-prenylnaringenin & hops & {$[9,101,188]$} & $0.057-0.51$ & $0.068-1.7$ \\
\hline Liquiritigenin & licorice & [189] & 2.80 & 0.41 \\
\hline Glabridin & licorice & [113] & 5.00 & $N D^{c}$ \\
\hline Glabrene & licorice & [190] & 1.00 & $N D^{c}$ \\
\hline Lindleyin & rhubarb & [124] & $225-435$ & $N D^{c}$ \\
\hline Trans-rhapontigenin & rhubarb & [129] & 12 & 5.6 \\
\hline Desoxyrhapontigenin & rhubarb & [129] & 26 & 28 \\
\hline Apigenin & chasteberry & {$[138,139,186]$} & 7.88 & $0.08-1.00$ \\
\hline Penduletin & chasteberry & [139] & $N^{c}$ & 0.31 \\
\hline
\end{tabular}

a The values are from different studies and are included for qualitative comparison. Different methods were employed: radiometric binding assay using purified human ER [9,50, $101,185]$, fluorescence polarization assay using purified human ER [124, 129, 138, 189], radiometric binding assay in cells or tissues [113, 187, 188, 190], inhibition ELISA using purified human ER [186], and dextran-coated charcoal method in cells [89]. ${ }^{\mathrm{b}}$ Some compounds might not be plant-specific. ${ }^{\mathrm{c}}$ ND: not determined

function, nausea, weight gain, and sleep disturbances associated with these remedies $[40,41]$. Therefore, some botanicals have been investigated for their potential serotonergic effects including activation of serotonin receptors, mainly $5-\mathrm{HT}_{7}$, or inhibition of serotonin reuptake through SERTs. What follows is a review of the potential mechanisms (estrogenic, progestogenic, serotonergic) of common botanicals for managing menopausal symptoms.

\section{Botanicals with Estrogenic Activity}

Due to the importance of estrogens in the alleviation of menopausal symptoms, particularly for the reduction of hot flashes, several popular botanicals have been studied for estrogenic activity including soy, red clover, kudzu, hops, licorice, rhubarb, yam, chasteberry, dong quai, and black cohosh ( $\bullet$ Table 1$)$. In vitro and in vivo experiments are summarized below describing elucidation of potential estrogenic activity of the extracts and isolation and characterization of their active principles.

Soy (Glycine max, Fabaceae) is often consumed as an alternative to HT by menopausal women [42]. Genistein and daidzein ( $\triangle \mathrm{Ta}$ ble 1, Fig. 3B) are the most abundant estrogenic compounds in soy [43]. They are mainly glycosylated in the extract and are activated upon hydrolysis in vivo, contributing to their estrogenic activity [44-46]. It has been shown that these flavonoids preferentially bind and activate ER $\beta$ in cell-based assays and that daidzein had weaker estrogenic activity compared to genistein ( $\bullet$ Table 1 ) [9,47-49]. It has also been reported that daidzein metabolism by the gut microflora results in the formation of S-equol ( $\bullet$ Table 1 , Fig. 3 B) which had a stronger estrogenic activity than daidzein in ER binding and transcriptional activation assays in HEC-1 cells [50]. S-equol activity was more significant with ER $\beta$, (Ki $[\mathrm{ER} \beta]=16 \mathrm{nM} ; \beta / \alpha=13$ fold), being comparable to that of genistein $(\mathrm{Ki}[\mathrm{ER} \beta]=6.7 \mathrm{nM} ; \beta / \alpha=16)[50,51]$. It has also been reported that gut microflora variability and differences in the metabolism of soy flavonoids could lead to individual variation in the amount of S-equol formed resulting in distinct biological outcomes [51-54].
Genistein, daidzein, and S-equol can also activate ER $\alpha$-dependent responses such as MCF-7 (ER $\alpha+)$ cell proliferation [55-61]. It has been demonstrated that activation of ER $\alpha$-dependent responses by genistein is associated with high concentrations of this isoflavone $[48,62,63]$, while ER $\beta$-dependent responses are mainly observed at low concentrations [9,62]. Wober et al. [64] observed a dose-dependent induction of alkaline phosphatase with genistein and daidzein in the endometrial adenocarcinoma cell line, Ishikawa $(E R \alpha+)$, an effect which was inhibited by the antiestrogen ICI 182,780, demonstrating an ER-dependent estrogenic activity. Similarly, Kayisli et al. [65] reported a weak but dose-dependent estrogenic activity with soy isoflavones in Ishikawa cells when they studied cell proliferation and alkaline phosphatase activity. In the presence of $E_{2}$, these compounds had antiestrogenic effects [65].

Consistent with the observed in vitro effects, subcutaneous injection of genistein $(250 \mathrm{mg} / \mathrm{kg} /$ day $)$ in ovariectomized SpragueDawley rats for two weeks significantly increased uterine weight, uterine-to-body weight ratio, femur weight, and femur-to-body weight ratio, all of which are likely ER $\alpha$-dependent effects [10]. Cimafranca et al. [66] also showed that $2 \mu \mathrm{L} / \mathrm{g}$ body weight of genistein $(25 \mathrm{mg} / \mathrm{mL})$ induced an increase in uterine weight, downregulated the progesterone receptor in uterine epithelium, increased multioocyte follicles, and decreased thymus weight relative to body weight in neonatal mice after 5 days. Some of the effects including increased multioocyte follicles and abnormal estrous cycle were also seen after 6 months. Legette et al. [67] observed an increased uterine weight and enhanced uterine proliferative index in ovariectomized Sprague-Dawley rats receiving $200 \mathrm{mg} / \mathrm{kg}$ dietary equol, demonstrating ER $\alpha$-dependent effects in vivo.

Similarly as in the isoflavone studies, soy extract bound to ER $\beta$ at $100 \mu \mathrm{g} / \mathrm{mL}$ and activated ER $\beta$-dependent transcription in HEK293 cells at $0.1-100 \mu \mathrm{g} / \mathrm{mL}$, while it did not have any proliferative effects in MCF-7 (ER $\alpha+)$ cells [68]. However, Vieira et al. [69] showed that different commercially available soy supplements increased uterine weight in immature female rats when applied at increasing serial doses (125-4150 mg/kg/day) for 3 days. The 


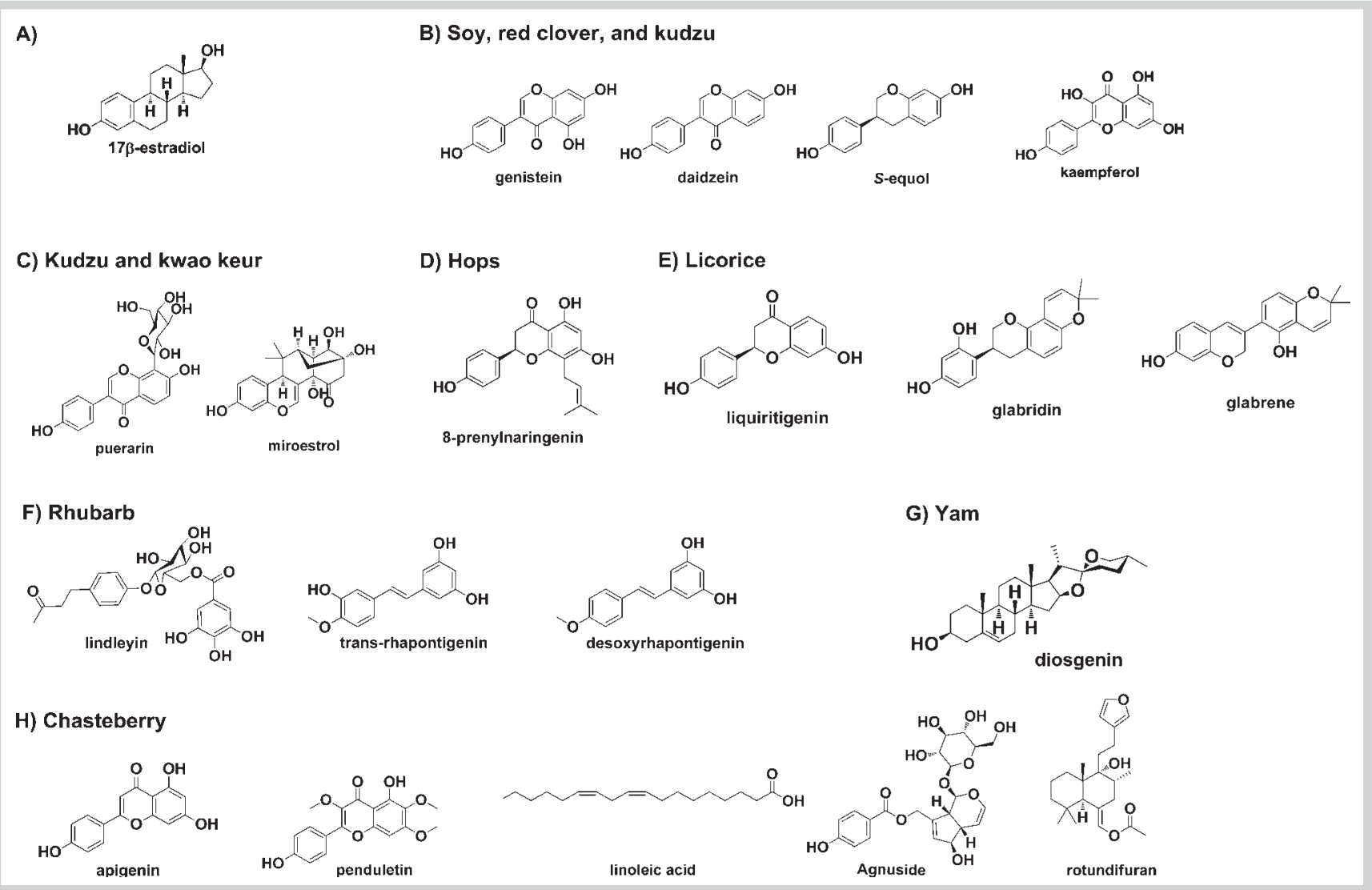

Fig. 3 Chemical structures of phytoestrogens found in the estrogenic botanicals.

observed proliferative effects could be due to the administration of high concentrations of the extract, which can activate ER $\alpha$-dependent pathways, similar to what was observed in experiments with high concentrations of isoflavones. In their studies, the uterotrophic effects were different when extracts from different vendors were used, demonstrating the lack of a unified standardization system in soy extract manufacturing. Allred et al. [70] showed that genistein alone, mixed soy isoflavones, Novasoy, molasses, and soy flour combined with mixed isoflavones have different effects on estrogen-dependent MCF-7 (ER $\alpha+$ ) tumor growth in athymic mice, demonstrating the effect of the food matrix on the modulation of estrogenic effects of soy and its contents. A thorough review by Hilakivi-Clarke et al. [71] concluded that the estrogenic effects of soy and its isoflavones in animal models are influenced by the dose, the route of administration, the matrix, and the age in which animals receive either whole soy or the isoflavones. In summary, soy contains genistein and daidzein which preferentially bind to and activate $\operatorname{ER} \beta$, but at higher concentrations and depending on the tissue, they can activate $E R \alpha$-dependent responses as well [71-73].

Red clover (Trifolium pratense, Fabaceae) is often used for the relief of menopausal symptoms [42], and it contains the same phytoestrogens including genistein and daidzein ( $\odot$ Table 1, Fig. 3 B) as discussed above for soy. However, unlike soy, the majority of the isoflavones in red clover are present as the methoxy ethers, formononetin and biochanin A, which require P450-catalyzed metabolism to generate the active phytoestrogens daidzein and genistein, respectively ( $\odot$ Fig. 4A) [43, 74]. In a chemical and biological evaluation, Booth et al. [75] reported that a standardized red clover extract $(0.23 \%$ daidzein, $0.41 \%$ genistein, $0.07 \%$ kaempferol, $14.26 \%$ formononetin, $14.47 \%$ biochanin A), preferentially bound to ER $\beta$ and induced alkaline phosphatase in Ishikawa cells $\left(\mathrm{EC}_{50}=2.0-2.2 \mu \mathrm{g} / \mathrm{mL}\right.$ ). In this study, daidzein and genistein were the most active constituents in the alkaline phosphatase induction assay in Ishikawa cells and in the competitive ER binding assay, with a preferential activity with ER $\beta$, while formononetin, biochanin $\mathrm{A}$, and kaempferol did not have estrogenic effects. Considering the abundance of formononetin and biochanin A in the extract, relative to daidzein and genistein, P450-catalyzed metabolism obviously plays an essential role in generating the estrogenic activity of the extract (O Fig. 4A) [75]. Hsu et al. [76] reported moderate estrogenic effects by biochanin $A$ in MCF-7 cells. Markiewicz et al. [77] showed that compared to $E_{2}$, genistein, and daidzein, induction of alkaline phosphatase by formononetin and biochanin A in Ishikawa cells is weak. Similarly, in a study by Fokialakis et al. [78], biochanin A weakly induced luciferase reporter activity in MCF-7:D5 L and alkaline phosphatase activity in Ishikawa cells as well as proliferation of MCF-7 cells. Halabalaki et al. [79] showed that formononetin moderately bound to ER subtypes. Compared to genistein and daidzein, formononetin weakly activated alkaline phosphatase in Ishikawa cells and luciferase reporter induction in MCF-7:D5 L cells [79]. This might further emphasize the role of metabolism in exerting estrogenic responses by red clover compounds. While Booth et al. [75] did not observe any estrogenic activity for kaempferol (O Fig. 3 B), Zoechling et al. [80] reported a selective binding of kaempferol to ER $\beta$ (O Table 1 ). 


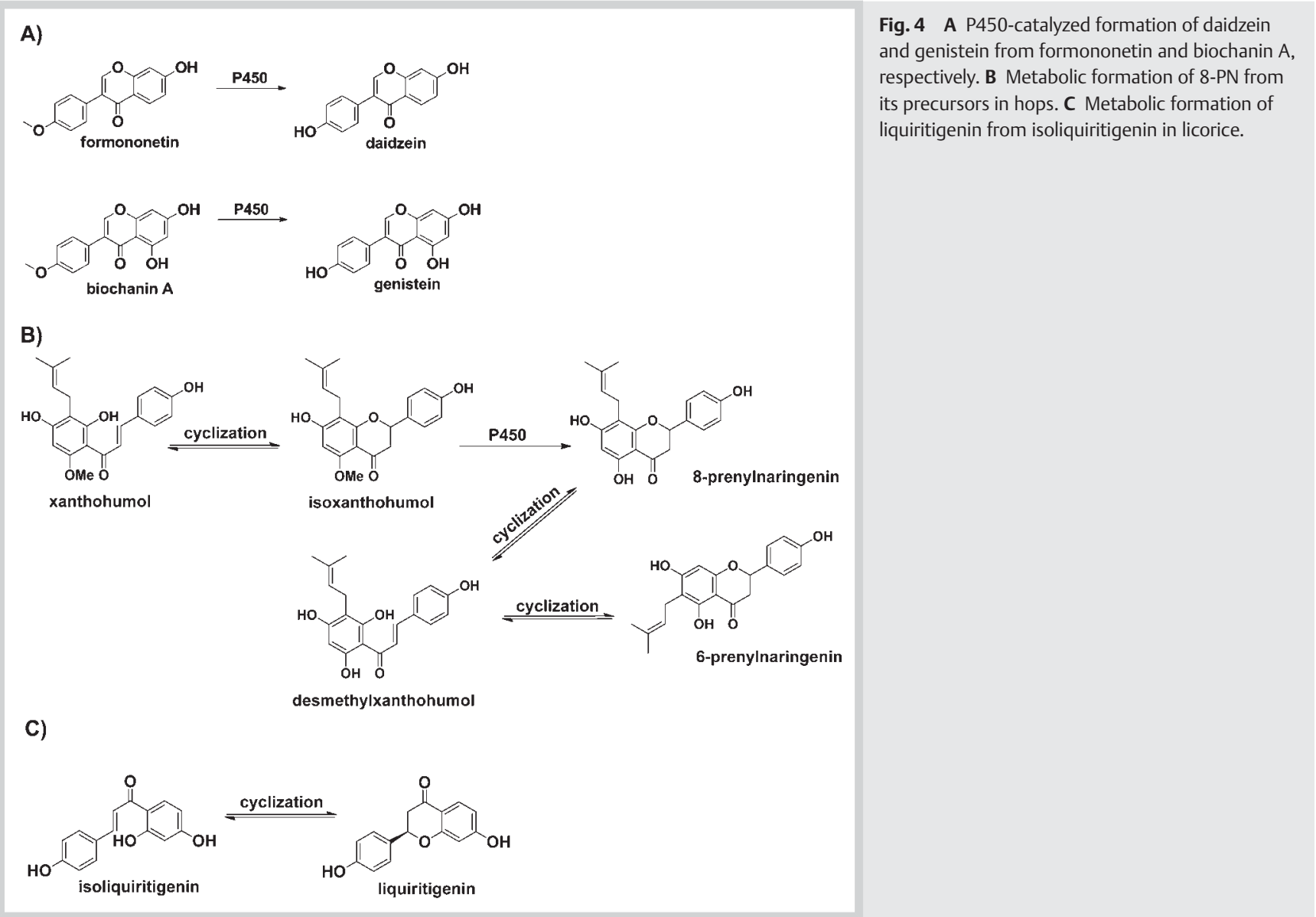

In another study, a weak estrogenic activity was reported for a red clover extract through binding and activation of ER $\beta$ in transfected HEK-293 cells but proliferative effects in MCF-7 (ER $\alpha+)$ cells, at concentrations $>30 \mu \mathrm{g} / \mathrm{mL}$ [68]. Interestingly, Overk et al. [9] also showed that red clover extract had binding affinity for both ER subtypes but a greater affinity for ER $\beta$. They also demonstrated that the extract induced ERE-luciferase and $P g R$ mRNA transcription in ER $\alpha+$ cell lines MCF-7 and Ishikawa as well as activating estrogen responsive alkaline phosphatase in Ishikawa cells ( $\mathrm{EC}_{50}: 2 \mu \mathrm{g} / \mathrm{mL}$ ). Red clover phytoestrogens, as well as the extract, have a greater affinity for ER $\beta$, but they can bind to and activate ER $\alpha$ at high concentrations, especially in cell lines such as MCF-7 and Ishikawa as well as estrogen-sensitive tissues, which have high levels of ER $\alpha$. Moreover, formation of the ER $\beta$ selective estrogenic constituents, genistein and daidzein, depends on P450-catalyzed metabolism which could influence the results of the cell-based assays, since some cultured cells such as Ishikawa do not metabolize formononetin and biochanin $\mathrm{A}$ to the active isoflavones [9].

Estrogenic activity of red clover has also been studied in animal models. In an in vivo study with Sprague-Dawley rats, Burdette et al. [81] showed that a red clover extract, standardized to isoflavones, increased the uterine weight and vaginal cell cornification, demonstrating an estrogenic response in these tissues while they did not observe any mammary gland ductal branching as a sign of estrogenic activity in the breast. This observation showed that red clover can activate $\mathrm{ER} \alpha$-dependent responses in vivo, but its effects might be tissue specific. On the other hand, in an in vivo study by Overk et al., in which Sprague-Dawley rats were treated with lower doses of red clover extract, no uterotrophic effects, vaginal cell cornification, or increase in the height of uterus luminal epithelial cells were observed [82]. In summary, red clover mainly contains formononetin and biochanin A, which are converted by $\mathrm{P} 450$ metabolism to genistein and daidzein and exert estrogenic effects, preferentially through ER $\beta$. Similar to soy flavonoids, the estrogenic activity of red clover and its flavonoids likely depend on the administered concentration, metabolism of isoflavones, and the target tissue [71-73].

Kudzu (Pueraria lobata; Fabaceae) is one of the commonly used botanical supplements in the United States [42]. Isoflavonoids such as formononetin, biochanin A, genistein, daidzein, and puerarin ( Table 1, Fig. 3B and C) are among the compounds that were isolated from this plant $[83,84]$. As discussed above, genistein and daidzein have estrogenic activity preferentially through ER $\beta$, but activate ER $\alpha$ pathways as well $[10,82]$. Puerarin is metabolized to daidzein by intestinal bacteria $[85,86]$.

Pueraria lobata extract has been shown to preferentially bind to and activate ER $\beta$ in HEK-293 cells transfected with ER subtypes but surprisingly had a proliferative effect in MCF-7 (ER $\alpha+)$ cells [68]. In this study, it was not mentioned if the kudzu extract also had any effect on the reporter gene activity in ER $\alpha$ transfected HEK-293 cells, and the relative ER subtype selectivity was not clearly stated. These controversial results might also be associated with using two different cell lines and the tissue specific behavior of the extract. As discussed above, the estrogenic constituents of kudzu, such as genistein and daidzein, can activate ER $\alpha$ dependent estrogenic responses such as proliferation at higher concentrations or in specific hormone responsive tissues. A vari- 
ety of studies using the yeast-based estrogenic assays reported various potencies for kudzu extracts $[35,36,45]$. The observed distinct effects could be related to the different extract preparations and standardization between studies.

Pueraria mirifica, another species of Pueraria (commonly called Kwao Keur) which is very popular in Southeast Asia, was shown to significantly promote proliferation of MCF-7 (ER $\alpha+)$ cells at $1 \mu \mathrm{g} / \mathrm{mL}$, and it was more estrogenic than Pueraria lobata extract $[87,88]$. The active compound was puerarin with a proliferative effect at $1 \mu \mathrm{M}$ [87]. It was also reported that miroestrol (๑ Fig. 3C), another compound in Pueraria mirifica, induced ERE-CAT reporter gene activity as well as cell growth in MCF-7 $(\mathrm{ER} \alpha+)$ cells, indicating estrogenic activity, mainly through ER $\alpha$ [89]. However, using a yeast-based estrogenic assay with ER subtypes, Boonchird et al. [90] observed an 8.5-fold higher relative potency for the plant extract with ER $\beta$ in comparison to ER $\alpha$. Nevertheless, it was reported that different concentrations of various extracts of Pueraria mirifica induced vaginal epithelium cornification, increased uterine weight and thickness, and attenuated body weight in ovariectomized rats [91-95], which are considered ER $\alpha$ effects. Higher concentrations of the extract as well as isoflavone content and the tissue specificity might induce both ER $\alpha$ - and ER $\beta$-dependent responses [30,72,73]. A thorough recent review by Malaivijitnond [96] summarized many biological studies and defined the effects of different cultivars of Pueraria plants from various regions and seasons as a potential source of existing discrepancies between different study outcomes. In summary, Pueraria species contain formononetin, biochanin A, genistein, daidzein, puerarin, and miroestrol. Miroestrol is a potent ER $\alpha$ ligand while genistein and daidzein preferentially bind to and activate ER $\beta$. However, depending on the concentration and target tissue, ER $\alpha$-dependent responses could be observed.

Hops (Humulus lupulus; Cannabaceae) is a popular botanical for its sleep-inducing effects, especially in Europe [97,98]. It is also present in some dietary supplements for managing menopausal symptoms [42]. Liu et al. [99] reported a moderate estrogenic activity for hops based on competitive ER binding activity, alkaline phosphatase induction, and $\operatorname{PgR}$ mRNA induction in Ishikawa cells. Overk et al. also reported estrogenic activity for a hops extract in competitive ER binding assays, ERE-luciferase induction in MCF-7 (ER $\alpha+)$ cells, PgR mRNA induction in MCF-7 and Ishikawa cells, and induction of alkaline phosphatase enzyme in Ishikawa cells $\left(\mathrm{EC}_{50}=1 \mu \mathrm{g} / \mathrm{mL}\right)$ [9]. 8-PN has been reported as the estrogenic component of hops, equipotent for both ER subtypes, with an activity greater than that of any of the known phytoestrogens ( Table 1, Fig. 3D) $[9,100,101]$. Bovee et al. [102] observed estrogenic activity of 8-PN in a yeast-based ER-dependent reporter assay. In this study, the potencies of 8-PN for ER $\alpha$ and $\operatorname{ER} \beta$ were 100 times and 3900 times less than that of estradiol, respectively. Milligan et al. [103] reported that 8-PN induced alkaline phosphatase in Ishikawa Var I cells $\left(\mathrm{EC}_{50}=4.41 \mathrm{nM}\right)$ and was active in a yeast-based estrogenic assay. They showed that administration of 8 -PN ( $15.9 \mathrm{mg} / \mathrm{kg} /$ day, equivalent to $100 \mu \mathrm{g} / \mathrm{mL})$ in the drinking water for $72 \mathrm{~h}$ increased vaginal mitosis in ovariectomized Swiss albino mice; however, they did not observe a significant increase in the uterine weight and the uterine mitosis response [103]. In contrast, Overk et al. [82] observed that 8-PN increased the uterine weight and the height of uterus luminal epithelial cells in Sprague-Dawley rats significantly; however, an ethanolic extract of hops standardized to its active constituent, 8-PN, and its metabolic precursors, including isoxanthohumol, xanthohumol, and desmethylxanthohumol (๑ Fig. 4B), did not induce ute- rotrophy, vaginal cell cornification, and changes in the height of uterus luminal epithelial cells. Similarly, an in vivo study by Diel et al. [104] in ovariectomized Wistar rats showed that subcutaneous administration of $8-\mathrm{PN}$ ( $10 \mathrm{mg} / \mathrm{kg} /$ day $)$ increased the uterine weight, the height of uterine epithelial, and the height of vaginal epithelial cells. Additionally, ER $\alpha$ and clusterin genes were downregulated and complement $\mathrm{C} 3$ was upregulated in the uterus, indicating estrogenic activity of 8-PN in this animal model [104]. Bolca et al. [105] showed that disposition of 8-PN in the women's breast tissue, after hop supplementation for 5 days was associated with the dose and the metabolism of the precursor compounds. It is believed that the formation of the estrogenic compound of hops, 8-PN, is closely related to the metabolism of its precursor, isoxanthohumol ( Fig.4B), by intestinal microbiota and therefore, subjects with varied microflora could experience different biological outcomes upon hops administration [105109]. The difference in uterotrophic effects and vaginal histology between hops and its active compound, 8-PN, could be related to the metabolism factor and/or to the other components of hops as an extract. Hops might contain natural progestins which could counteract the estrogenic effects of 8-PN (discussed in the progestogenic effects section) [11]. Moreover, uterotrophy and vaginal cell histology are not the only measures of estrogenicity. Hops as an estrogenic extract might have more pronounced estrogenic effects in other target tissues, such as bone, cardiovascular, and brain which were not evaluated in these studies. In summary, hops flavonoid, 8-PN, is the most potent phytoestrogen known to date and is equipotent for ER subtypes. Since its formation depends on the metabolism of its precursors in hops, the estrogenic activity of hops extract might vary between different subjects depending on their metabolism characteristics.

Licorice (Glycyrrhiza species, Fabaceae) is a widely used plant, mainly as a sweetening agent in tobacco, in food and beverages, and in toothpastes. It consists of more than 30 species from which a few have been studied for several biological effects such as antibacterial, antiulcer, anti-inflammation, estrogenic, and chemopreventive [110]. Licorice is a common botanical in menopausal supplements in the United States, either as a single herb or in combination with other herbs [42]. The estrogenic activities of different licorice species and extracts are not the same. For example, Liu et al. [99] did not observe any estrogenic effects with the methanolic extract of Glycyrrhiza glabra (European licorice, the most common licorice species) when tested in the competitive ER binding assay, alkaline phosphatase induction in Ishikawa cells, Tff1 mRNA induction in S30 cells, and $P g R$ mRNA induction in Ishikawa cells. However, Dong et al. [111] showed that the boiling water extract of Glycyrrhiza glabra stimulated MCF-7 (ER $\alpha+$ ) cell growth at concentrations of $0.1-10 \mu \mathrm{g} / \mathrm{mL}$ and enhanced ProAB/luciferase activity in the same cell line at a range of 1$10 \mu \mathrm{g} / \mathrm{mL}$, which was comparable to the estradiol effect at $10 \mathrm{nM}$. In this study, the induction of estrogen responsive genes and the activation of rapid signaling pathways through Erk1/2 and $A k t$ in the proliferation of MCF-7 (ER $\alpha+)$ cells was observed at $10 \mu \mathrm{g} / \mathrm{mL}$ of the extract, demonstrating the role of this extract in activating the nonclassical mechanism of estrogenic activity [111]. Simons et al. [112] also observed estrogenic activity for several fractions of an ethyl acetate extract of Glycyrrhiza glabra in the yeast-based estrogenic assays. The activity of some fractions was abolished in the presence of either RU58668, a selective ER $\alpha$ antagonist, or (R,R)-5,11-diethyl-5,6,11,12-tetrahydro-2,8chrysenediol $(R, R-\mathrm{THC})$, a selective ER $\beta$ antagonist, demonstrating the ER-mediated estrogenic effects. The difference between 
the outcomes of these studies could be associated with using different extracts and concentrations tested as well as the various sources of the plant species. Simons et al. [112] also showed that glabrene-rich fractions of Glycyrrhiza glabra extract were more estrogenic with a higher potency for $\mathrm{ER} \alpha$, while glabridin ( Table 1, Fig. 3E) had antiestrogenic properties. However, Tamir et al. [113] showed that glabridin bound to ER in T47D cell extract (IC $50: 5 \mu \mathrm{M}$ ) stimulated ER-dependent cell growth at concentrations lower than $10 \mu \mathrm{M}$ and inhibited cell growth at concentrations higher than $15 \mu \mathrm{M}$ in an ER-independent manner. They also observed increased activation of creatine kinase, a marker of estrogenic activity, in female rat uterus, epiphyseal cartilage, diaphyseal bone, and cardiovascular tissues as well as an increased uterine weight effect comparable to that of $E_{2}$. Similarly, Somjen et al. [114] showed that glabridin better than glabrene activated creatine kinase in cultured female human bone cells as well as in female rat skeletal tissues. They also reported the estrogenic activity of glabrene and glabridin in vascular tissues in vitro and in vivo, with glabrene having selective estrogen receptor modulating-like effects [115].

The other popular species of licorice, Glycyrrhiza uralensis (Chinese licorice) was also reported to be estrogenic in yeast-based estrogen receptor activity assays, but the reported activities from different studies were not the same, indicating the lack of a unified standardized extract $[116,117]$. Glycyrrhiza uralensis extract was reported to stimulate MCF-7 (ER $\alpha+)$ cell growth at concentrations of $10-100 \mu \mathrm{g} / \mathrm{mL}$ with the maximal growth stimulation comparable to that of estradiol at $1 \mathrm{nM}$ [118]. Cell cycle analysis indicated an increased population of cells in the $S$ phase, and Western blots showed increased PCNA levels in response to proliferative concentrations of the extract, confirming an enhanced cell growth. They also demonstrated reduced levels of ER $\alpha$ protein as a marker of estrogenicity and a dose-dependent induction of pS2 (Tff1) and GREB1 mRNA [118]. These data showed ER $\alpha$-dependent estrogenic effects by the Glycyrrhiza uralensis extract. In contrast, an undefined licorice extract was reported to have no proliferative effects in MCF-7 (ER $\alpha+)$ cells and no uterotrophic effects in animal models, but possessed ER $\beta$ selectivity in ERE-luciferase induction in transfected HeLa cells [119]. The contradictory results could be associated with using different extracts which demonstrates the importance of having well-defined standardized licorice extracts.

Studying various species of licorice cultivated in different regions of the world, Kondo et al. [120] reported that Glycyrrhiza uralensis and Glycyrrhiza glabra had the highest and the lowest amounts of liquiritigenin ( Table 1, Fig. 3E), an estrogenic principle of licorice, respectively. Liquiritigenin was reported to be a highly selective ER $\beta$ agonist in the ER binding assay and ER $\beta$-EREluciferase induction assay in U2OS cells [121]. This flavonoid did not enhance proliferation of MCF-7 (ER $\alpha+)$ xenograft or induction of uterine weight in nude mice, confirming its better potency for $\mathrm{ER} \beta$ and the corresponding pathways [121]. Isoliquiritigenin ( Fig. 4C), the precursor of liquiritigenin, was reported to have estrogenic effects [122]. However, the observed effects could be associated with the conversion of isoliquiritigenin to liquiritigenin. Therefore, Glycyrrhiza uralensis is expected to exhibit stronger ER $\beta$-dependent effects, since it contains the highest amount of liquiritigenin. However, activation of ER $\alpha$-dependent responses such as increased proliferation markers could also be observed in some tissues and/or at higher concentrations [72, 73]. In summary, the most common licorice species in dietary supplements is Glycyrrhiza glabra which contains glabridin and glabrene in addition to liquiritigenin, while Glycyrrhiza uralenis contains the highest amount of liquiritigenin, an ER $\beta$ selective phytoestrogen. More in depth studies are needed to define the estrogenic effects of licorice in vitro and in vivo.

Rhubarb (Rheum species, Polygonaceae) is also a common herb for menopausal symptoms [42]. A variety of estrogenic activities have been reported for rhubarb extracts. For example, a Rheum undulatum (rhizome) extract in a yeast-based assay gave an $\mathrm{EC}_{50}=80 \mu \mathrm{g} / \mathrm{mL}$ with a relative potency of 100 times lower than that of estradiol [117]. Rheum palmatum (root) extracts were reported to have relative potencies of 2500 and 10000 times lower than that of estradiol in the yeast-based estrogenic assays [116, 123]. It was also shown that a rhubarb extract (species not defined) induced ERE-luciferase in ER $\alpha /$ ER $\beta$ transfected TSA201 cells, dose-dependently and the active constituent was lindleyin ( Table 1, Fig. 3F) with a relative binding potency of 20000 times lower than that of estradiol for ER $\alpha$. The extract increased vitelogenin (a marker of estrogenic activity) levels in the serum of Japanese Medaka [124]. These studies showed that different rhubarb species might have a weak to moderate ER-dependent estrogenic potential. An extract of Rheum rhaponticum (root), which is very popular in Germany, has also been studied. Wober et al. [125] showed that the extract activated reporter gene induction through ER $\beta$ in transfected HEC-1B adenocarcinoma cells. Similarly, Moller et al. [126] reported an ER $\beta$ activity of the extract in U2OS cells. A three-day in vivo study on ovariectomized rats by Papke et al. [127] showed that the rhubarb extract did not induce uterotrophy or markers of proliferation. Interestingly, administration of the extract in the presence of low doses of estradiol (menopausal conditions) suppressed the uterotrophic effects of estradiol, demonstrating an antiestrogenic effect. An extended in vivo study for 90 days with ovariectomized rats also confirmed that the rhubarb extract did not induce uterotrophy or markers of proliferation, while it showed no effect on the bone mineral density [128]. Vollmer et al. [129] also reported that different doses of the rhubarb extract did not enhance the uterine wet weight and the proliferation marker genes in ovariectomized rats. Interestingly, when the extract was combined with $E_{2}$, it counteracted the uterotrophic effects of $E_{2}$, dose-dependently [129]. They reported that the two compounds, trans-rhapontigenin and desoxyrhapontigenin ( Table 1, Fig. 3F), from the extract bound to both ER subtypes with a slight preference for ER $\beta$ [129]. Activation of ER $\beta$ with rhubarb might be the reason that the extract does not show proliferative effects in uterine tissue, and its antiestrogenic effects could be related to its partial agonistic effects for ERs, which manifest as antagonistic activity when the full agonist, estradiol, is present. In summary, rhubarb is mainly an ER $\beta$ activating plant, although its reported active compounds, lindleyin, rhapontigenin, and desoxyrhapontigenin, are not ER $\beta$-selective.

Yam (Dioscorea species, Dioscoreaceae) is a common botanical for managing menopausal symptoms [42]. Park et al. [130] showed that yam extract at a high concentration $(200 \mu \mathrm{g} / \mathrm{mL})$ induced $P g R$ and pS2 mRNA in MCF-7 cells after $24 \mathrm{~h}$. These effects were inhibited when the treatment was combined with ICI 182,780 $(1 \mu \mathrm{M})$, indicating an ER-dependent pathway. Similar to $E_{2}$, yam extract reduced the levels of ER $\alpha$ protein and mRNA, measured by Western blot and RT-PCR. This effect was also blocked by ICI 182,780 , showing the estrogenic potential of yam extract. On the other hand, the extract was antiproliferative in MCF-7 $(\mathrm{ER} \alpha+)$ cells when applied at $20-200 \mu \mathrm{g} / \mathrm{mL}$ for $72 \mathrm{~h}$ suggesting that the estrogenic yam extract did not promote estrogen-depen- 
dent tumor cell growth [130]. However, the type of the extract and the species of yam was not defined in this study. Our own observations with yam (Dioscorea villosa) showed that the methanolic extract was toxic to Ishikawa and MCF-7 (ER $\alpha+)$ cells at concentrations $>5 \mu \mathrm{g} / \mathrm{mL}$, and therefore the estrogenic activity could not be evaluated (unpublished data). Cheng et al. [131] showed that the ethyl acetate extract of yam (Dioscorea alata) at $10 \mu \mathrm{g} / \mathrm{mL}$ weakly induced the transcriptional activation of GAL4responsive alkaline phosphatase reporter in CHO-K1 cells with either ER subtypes, with a slightly stronger activity with ER $\alpha$. Similarly, when yam (Dioscorea alata) was given to menopausal women at $390 \mathrm{~g} /$ day as part of their food for 30 days, a significant increase in serum concentrations of estrone, sex hormone binding globulin (SHBG), and an increase in estradiol was observed, showing that the yam diet enhanced the hormone levels in these subjects [132]. Diosgenin ( Table 1, Fig. 3G) isolated from yam, was used in pharmaceutical industry to synthesize progesterone and cortisone [133] and was shown to have estrogenic activity in an animal model [134]; however, there are few recent reports about its estrogenic activity. The concentration of diosgenin is relatively low in yam species, and it will not biochemically convert to estrogens in vivo [131]. Therefore it is not clear, how yam ingestion could lead to increased estrogen levels in menopausal women and which components might be the active principle(s). Chasteberry (Vitex agnus-castus, Lamiaceae) is also a popular botanical added to botanical supplements for women's health [42]. It was shown to have a weak binding affinity for ERs and no alkaline phosphatase induction in Ishikawa cells; however, it induced $P g R$ mRNA in this cell line [99]. Activation of $P g R$ while other estrogenic markers are negative could be associated with possible progestogenic effects of chasteberry (discussed in progestogenic effects section). Liu et al. [135] reported that the methanolic extract of Vitex agnus-castus had a weak binding affinity for ERs (IC ${ }_{50}$ ER $\alpha=46 \mu \mathrm{g} / \mathrm{mL}, \mathrm{ER} \beta=64 \mu \mathrm{g} / \mathrm{mL}$ ) and upregulated ER $\beta$ mRNA in T47D:A18 and PgR in Ishikawa cells, while inducing alkaline phosphates enzyme in Ishikawa cells. Linoleic acid ( $\bullet \mathbf{F i g . 3 H}$ ) has been found as the "active" estrogenic component of chasteberry based on bioassay-directed fractionation of the crude extract using the ER binding assay. In this study, while linoleic acid induced ER $\beta$ in T47D:A18 cells and PgR in Ishikawa cells, it did not induce alkaline phosphatase activity in Ishikawa cells. However, linoleic acid is a fatty acid and may contribute to nonspecific binding to ERs and PRs, generating false positive results [135]. Ibrahim et al. [136] showed that an ethanolic extract of Vitex agnus castus increased uterine weight in Sprague-Dawley rats in addition to an increase in the plasma levels of progesterone and estrogen and a decrease in LH and prolactin, suggesting an estrogenic effect of chasteberry. It was shown that chasteberry extract had a selective binding to ER $\beta$, and bioassay-guided fractionation of the crude extract led to the isolation of apigenin ( Table 1, Fig. $3 \mathbf{H}$ ), the most selective ER $\beta$ ligand in this plant [137]. Choi et al. [138] also observed ER $\beta$ selectivity with apigenin in the competitive binding assay in addition to estrogenic activity in the yeast-based assay and MCF-7 (ER $\alpha+)$ cell growth. Based on these studies, apigenin can preferentially activate ER $\beta$-dependent responses; but can also stimulate $E R \alpha$-dependent effects at higher concentrations or in certain tissues. Apigenin could also induce progestogenic activity (discussed in progestogenic effects section) [11]. Jarry et al. [139] isolated penduletin ( $\bullet$ Table 1, Fig. $3 \mathrm{H}$ ) from chasteberry, which was also an ER $\beta$ selective agonist in the ER binding assay $\left(\mathrm{IC}_{50}: 0.31 \mu \mathrm{M}\right)$. However, the presence of ER $\beta$ ligands in chasteberry in addition to the progesto- genic effects of apigenin did not oppose the proliferative responses of chasteberry extract in vivo [136], which could be associated with the amounts of these compounds in the plant extract and their insufficient bioavailability.

Hu et al. [140] reported MCF-7 (ER $\alpha+)$ cell proliferation with four different species of Vitex. They reported that the essential oil of Vitex rotundifolia, which was mainly composed of linoleic acid, strongly stimulated MCF-7 $(E R \alpha+)$ cell proliferation, the effect which was inhibited by ICI 182,780 , demonstrating an ER $\alpha$-dependent activity of the linoleic-rich fractions [141]. Additionally, they found that Vitex rotundifolia and its components agnuside ( $\odot$ Fig. $3 \mathbf{H}$ ) and rotundifuran ( $\odot$ Fig. 3H) induced MCF-7 (ER $\alpha+$ ) cell proliferation, EST1 (ER $\alpha$ ), PgR, and Tff1 mRNA dose-dependently and the effects were inhibited by ICI 182,780 [142]. Therefore, according to distinct chemical profiles and biological activities of different Vitex species, identification of the species is very important, especially for the standardization of the botanical supplements. In summary, Vitex species have estrogenic properties, and compounds such as apigenin and penduletin are their ER $\beta$-selective compounds, while rotundifuran and agnuside have been reported to activate $\mathrm{ER} \alpha$-dependent responses.

Dong quai (Angelica sinensis, Apiaceae) is another popular botanical for managing menopausal symptoms as well as women's health issues in general [42]. The estrogenic activity of dong quai is still controversial [143]. For example, Amato et al. [119] reported that dong quai had proliferative effects in MCF-7 (ER $\alpha+)$ cells but did not activate ER $\alpha / E R \beta$-dependent luciferase transcription in transfected HeLa cells and did not exert uterotrophic effects in CD-1 mice. However, Circosta et al. [144] observed increased uterine weight, modified vaginal cytology, and reduced luteinizing hormone levels in female Wistar rats treated with an ethanolic extract of dong quai. Similarly, cell based investigations revealed controversial results. Liu et al. [99] reported that dong quai methanolic extract did not bind to ERs, induce alkaline phosphatase activity in Ishikawa cells, or induce estrogen sensitive genes (PgR and Tff1) mRNA in Ishikawa and S30 cells, respectively. Similarly, Zhang et al. [123] published that an ethanolic extract of dong quai was not estrogenic in a yeast-based assay over the concentration range of $0.1-1000 \mu \mathrm{g} / \mathrm{mL}$. A recent study showed that wine-processed dong quai extract at $1 \mathrm{mg} / \mathrm{mL}$ (very high concentration) had no proliferative effect on MCF-7 (ER $\alpha+$ ) cells but it induced ERE-luciferase [145]. On the other hand, Lau et al. [146] observed proliferation of MCF-7 (ER $\alpha+)$ cells with dong quai concentrations $>100 \mu \mathrm{g} / \mathrm{mL}$, which could be blocked by 4-hydroxytamoxifen, demonstrating a weak ER-dependent estrogenic activity. Interestingly, Rosenberg-Zand et al. [147] showed that an ethanolic extract of dong quai blocked Tff1 mRNA induction in BT474 breast cancer cells, demonstrating an antiestrogenic effect by this herb. Similarly, Godecke et al. [148] reported that the lipophilic fraction of a methanolic extract (rich in ligustilide) of dong quai at $20 \mu \mathrm{g} / \mathrm{mL}$ significantly inhibited alkaline phosphatase induction in the presence of estradiol in Ishikawa cells, suggesting an antiestrogenic potential. To date, there have been no reports of a purified compound which could be responsible for the observed estrogenic/antiestrogenic properties of dong quai. These studies demonstrate that additional studies with well-defined extracts are needed in order to delineate the estrogenic/antiestrogenic potential of dong quai as well as the active compound. One reason for the contradictory results regarding the estrogenic activities of dong quai could be associated with the instability of its phthalide fractions, in particular 
ligustilide [149]. Conclusive data on the relative estrogenic effects of dong quai are currently unavailable.

Black cohosh (Cimicifuga racemosa, Ranunculaceae) is the most popular botanical for menopausal symptom relief in the United States [42]. However, reports of its estrogenic activities are controversial [150]. Liu et al. [99] showed that black cohosh did not bind to ERs, did not induce alkaline phosphatase in Ishikawa cells, or induce PgR and Tff1 mRNA in Ishikawa and S30 cells, respectively. Amato et al. [119] confirmed these results when they reported that black cohosh did not induce MCF-7 (ER $\alpha+)$ cell proliferation, ERE-luciferase in tranfected HeLa cells, and uterotrophic effects in animal models. Bodinet et al. and Freudenstein et al. $[151,152]$ showed that standardized isopropyl extract of black cohosh inhibited proliferation of estrogen-dependent MCF-7 $\left(E R \alpha^{+}\right)$cells, dose-dependently. Similarly, Gaube et al. [153] showed that a dichloromethane extract of black cohosh inhibited MCF-7 (ER $\alpha^{+}$) cell proliferation dose-dependently ( $\mathrm{IC}_{50}: 14.7 \mu \mathrm{g} /$ $\mathrm{mL}$ ), and the majority of proliferation control and proapoptotic genes were down-regulated. Lupu et al. [154] also did not observe any estrogenic effect with black cohosh in an array of estrogenic assays in estrogen responsive cells. Similarly, Zierau et al. [155] reported that ethanolic and isopropyl extracts of black cohosh did not enhance MCF-7 (ER $\alpha+$ ) cell proliferation and did not show estrogenic effects in the yeast-based assay and ERE-luciferase assay in MCF-7 (ER $\alpha+)$ cells. Interestingly, the extracts inhibited estradiol-induced MCF-7 (ER $\alpha+)$ cell proliferation and mRNA expression, demonstrating possible antiestrogenic effects of the black cohosh extracts. It was also shown that isopropyl extract of black cohosh did not influence the uterine weight and vaginal cytology in Sprague-Dawley rats in the presence or absence of estradiol [156]. Mercado-Feliciano et al. [157] also did not observe any estrogenic or antiestrogenic effects in the uterus of female B6C3F1/N mice treated with different doses of an ethanolic extract of black cohosh for 3 days. Another study also demonstrated no classical estrogenic effects in ovariectomized rats after three months of treatment with an ethanolic extract of black cohosh [158]. Ruhlen et al. [159] observed a reduction of hot flashes in women taking a black cohosh extract containing $2.5 \%$ triterpenes for 12 weeks. The effect returned to baseline after a 12 -week washout period. The extract did not have any effect on serum estrogenic markers, $p S 2$ expression levels, and cellular morphology in the women's nipple aspirate fluids, demonstrating no detectable estrogenic effect on the breast tissue [159]. In contrast, Liu et al. [160] observed a significant MCF-7 (ER $\alpha+)$ cell growth and ER upregulation in response to a black cohosh treatment, but they did not mention the type of the extract. Bolle et al. [161] also reported a weak estrogenic activity for black cohosh in the yeast estrogenic assay; however, they did not observe a uterotrophic effect with the extract. It is still not clear whether black cohosh has estrogenic activity or other mechanisms of action (i.e., serotonergic discussed below) even though it is currently the most popular dietary supplement used by menopausal women [162].

\section{Botanicals with Progestogenic Activity \\ $\nabla$}

Unlike estrogenic reports on botanicals, there are relatively few studies on potential progestogenic effects. Evidence about the progestogenic potential of botanicals including red clover, hops, yam, and chasteberry are summarized.

Red clover (Trifolium pratense, Fabaceae) ethanolic extract was shown to induce PRE-luciferase in T47D cells at $20 \mu \mathrm{g} / \mathrm{mL}$ by 4.7 - fold. It also bound to $\mathrm{PR}\left(\mathrm{IC}_{50}=34 \mu \mathrm{g} / \mathrm{mL}\right)$ showing a weak progestogenic effect [11]. In the same study, Toh et al. showed that kaempferol ( $\odot$ Fig. 5B) from red clover at $10 \mu \mathrm{M}$ induced PRE-luciferase in T47D cells by 5.5 -fold, while it bound to PR with an $\mathrm{IC}_{50}=1.5 \mu \mathrm{M}$. Kaempferol also antagonized progesterone receptor in PRE-luciferase assay in T47D cells in the presence of progesterone (100 nM), suggesting that kaempferol was a PR partial agonist. However, the concentration of kaempferol is low and its PR activity is weak suggesting that there might be other natural as yet unidentified progestins in this botanical. The presence of these progestins might be the reason that Overk et al. [82] did not see uterotrophic effects in Sprague-Dawley rats treated with red clover.

Hops (Humulus lupulus, Cannabaceae) did not induce uterine weight in Sprague-Dawley rats, even though its estrogenic compound, 8-PN, had a significant estrogenic effect [82]. These observations could be explained by natural progestins in hops which might oppose the estrogenic activity of 8-PN. An ethanolic extract of hops at $20 \mu \mathrm{g} / \mathrm{mL}$ was reported to weakly induce PRE-luciferase as a marker of progestogenic activity in T47D cells [11]. A progestogenic compound of hops was not defined in this study. These data were inconclusive since the hops extract interfered with the binding data from the fluorescence polarization assay, and the extract was toxic in the PRE-luciferase assay. In contrast, Milligan et al. [100] did not observe any progestogenic effects with hops and its major flavonoids in the yeast-based progestogenic assay.

Yam (Dioscorea species, Dioscoreaceae) contains diosgenin (O Fig. 5D) which could have hormonal effects [163]. Diosgenin (500 mg) was continuously administered to Sprague-Dawley rats for 47 days, and the effects on kidney structure were compared to the intact control group and ovariectomized group [164]. The body weight and kidney wet weight of ovariectomized animals increased compared to control and diosgenin-treated groups. Morphometrical analysis of glomerular length and kidney area between the three groups suggested that diosgenin protected the kidney from morphological changes associated with ovariectomy. The effects were likely due to progestogenic effects produced by the conversion of diosgenin to progesterone [164].

Chasteberry (Vitex species, Lamiaceae) was observed to have a weak PRE-luciferase activity at $20 \mu \mathrm{g} / \mathrm{mL}$ in T47D cells [11]. In the same study, Toh et al. also showed a significant (6.5-fold) induction of PRE-luciferase activity by a component of chasteberry, apigenin ( $\odot$ Fig. $5 \mathrm{C}$ ), at $10 \mu \mathrm{M}$ and a good PR binding affinity $\left(\mathrm{IC}_{50}=1 \mu \mathrm{M}\right)$, suggesting a possible progestogenic effect [11]. However, the concentration of apigenin in chasteberry is low which explains the weak progestogenic activity of this botanical. Lu et al. [165] also showed that wild female Phayres's leaf monkeys consuming Vitex species had an altered endocrine function resulting in higher fecal progestin levels. This in turn could influence the cycle length and reproductive function in these animals. Another study on wild female Chimpanzees showed that consumption of Vitex fischeri for 6 weeks caused an abrupt and significant increase in the urinary progesterone levels without any significant influence on estrogen levels [166]. However, none of these studies explored the physiological basis of these endocrine alterations in the studied subjects. Further studies are needed to confirm the progestogenic effects of Vitex species in animal models and humans. 


A) B) Red clover C) Chasteberry D) $\mathrm{Yam}$

Fig. 5 Chemical structures of phytoprogestins found in botanicals.

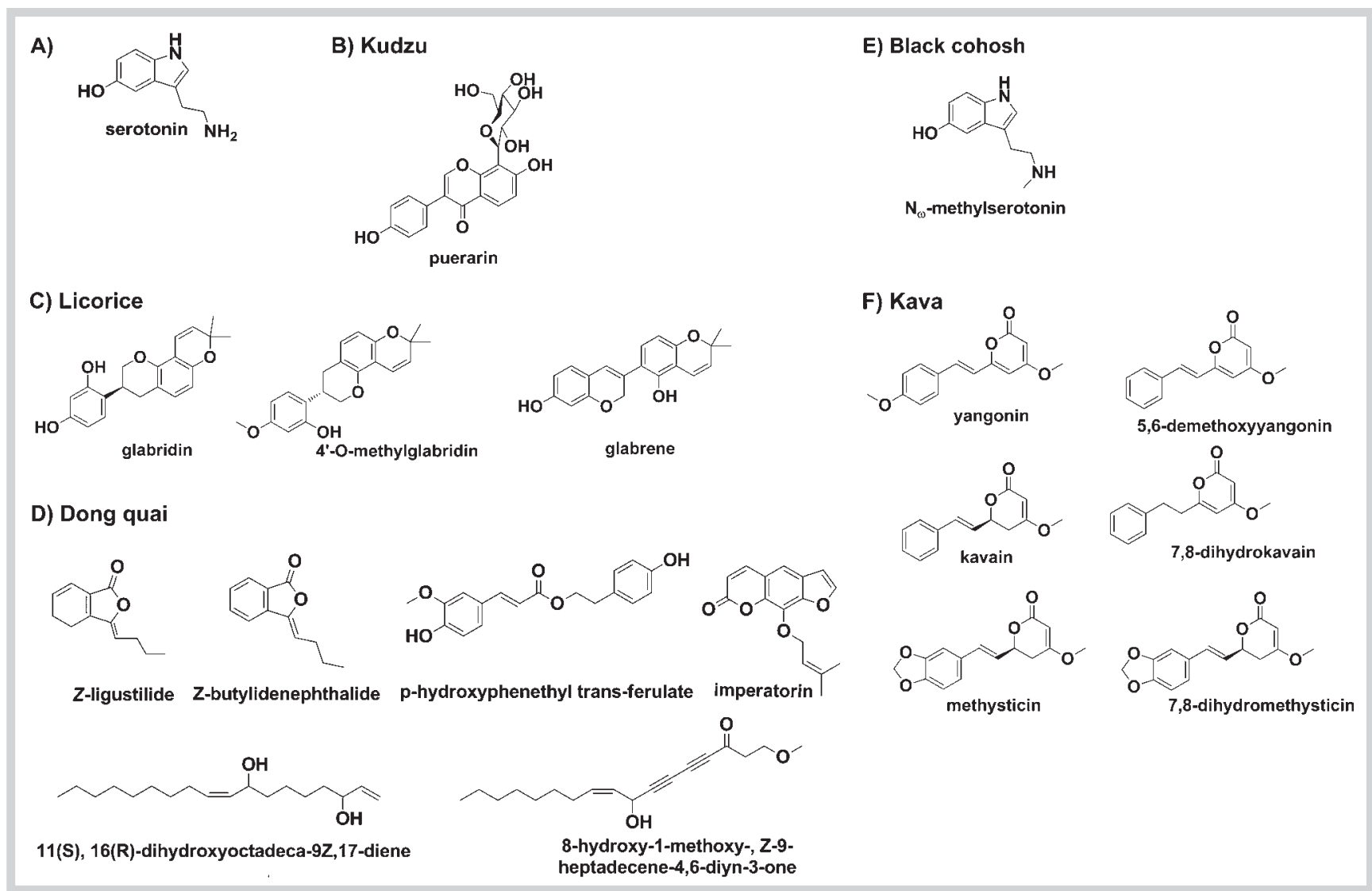

Fig. 6 Chemical structures of serotonergic compounds found in botanicals.

\section{Botanicals with Serotonergic Activity \\ $\nabla$}

Some botanicals such as black cohosh are widely used for managing menopausal symptoms, although there is little evidence for their hormonal effects $[150,162]$. Since there have been reports of relief of hot flash intensity and frequency by SSRIs [167], botanicals have been studied for potentially similar mechanisms.

Black cohosh (Cimicifuga racemosa, Ranunculaceae) probably does not have estrogenic activity as discussed above. However, it remains one of the most popular botanical supplements for menopausal symptoms implying alternative efficacy mechanisms. Therefore, black cohosh was studied for its potential serotonergic effects [156]. A black cohosh isopropyl extract was shown to inhibit the binding of $\left[{ }^{3} \mathrm{H}\right]$ lysergic acid diethylamide to $5-\mathrm{HT}_{7}$, one 5-HT-subtype that is associated with thermoregulation in the hypothalamus $\left(\mathrm{IC}_{50}=2.4 \mu \mathrm{g} / \mathrm{mL}\right)$ [156]. In the same study, Burdette et al. showed that a methanolic extract of black cohosh elevated cAMP levels in 5- $\mathrm{HT}_{7}$ transfected HEK 293 cells, suggesting that the extract acted as a partial agonist of the receptor. This effect was reversed in the presence of methiothepin, the antagonist of
$5-\mathrm{HT}_{7}$, suggesting a receptor-mediated process. Powell et al. [12] also showed that the methanolic extract of black cohosh displayed $5-\mathrm{HT}_{7}$ binding activity and induced cAMP production. Using bioassay-guided fractionation, $\mathrm{N}_{\omega}$-methylserotonin ( Fig. 6E) was identified as a potent ligand for the 5- $\mathrm{HT}_{7}$ receptor $\left(\mathrm{IC}_{50}=23 \mathrm{pM}\right)$ which induced cAMP production $\left(\mathrm{EC}_{50}=\right.$ $22 \mathrm{nM}$ ) and blocked serotonin reuptake $\left(\mathrm{IC}_{50}=490 \mathrm{nM}\right)$. Nadaoka et al. [168] observed that black cohosh attenuated the conversion of 5-HT to its metabolite 5-hydroxyindoleacetic acid in the hypothalamus, hippocampus, and cortex of the mice subjected to an acute immobilization stress, demonstrating elevated levels of 5HT upon black cohosh administration. Although the clinical trials on the efficacy of black cohosh in relieving menopausal symptoms are not conclusive $[169,170]$, the positive effects reported by some women might be attributed to its ability to activate serotonin receptors and block serotonin reuptake, leading to enhanced serotonergic activity. More animal model studies are necessary to provide further evidence for serotonergic activity of black cohosh. 
Kudzu (Pueraria lobata, Fabaceae) methanolic extract at a high concentration $(2 \mathrm{~g} / \mathrm{kg})$ as well as puerarin $(1-30 \mathrm{mg} / \mathrm{kg})$ (๑ Fig. 6B) systemic administration in male Sprague Dawley rats induced hypothermia [13]. The same effect was observed with i.c. v. injection of 50-100 $\mu \mathrm{g}$ of puerarin. A significant correlation between the measured hypothermia and reduced 5-HT efflux in the rat hypothalamus was observed, indicating the role of the serotonergic system in inducing hypothermia by kudzu extract and puerarin as its active compound [13]. The well-known components of kudzu, soy, and red clover, genistein $(10 \mathrm{nM}-10 \mu \mathrm{M})$, were shown to stimulate $\left[{ }^{3} \mathrm{H}\right]$ serotonin uptake in transfected COS-7 cells, demonstrating its potential serotonergic effects [171].

Kava (Piper methysticum, Piperaceae) was shown to have neurotransmitter-like effects [172]. The extract of kava leaves was reported to have $\mathrm{GABA}_{\mathrm{A}}$ receptor binding activity $\left(\mathrm{IC}_{50}=3 \mu \mathrm{g} / \mathrm{mL}\right)$, dopamine $\mathrm{D} 2$, opioid ( $\mu$ and $\delta$ ), and histamine $\left(\mathrm{H}_{1}\right.$ and $\left.\mathrm{H}_{2}\right)$ receptor binding activity $\left(\mathrm{IC}_{50}=1-100 \mu \mathrm{g} / \mathrm{mL}\right)$ as well as a weak binding to serotonin ( $5-\mathrm{HT}_{6}$ and $5-\mathrm{HT}_{7}$ ) and benzodiazepine receptors [172]. The active principles of kava with serotonergic activities were reported to be the kavalactones including, kavain, 7,8-dihydrokavain, methysticin, 7,8-dihydromethysticin, yangonin, and 5,6-demethoxyyangonin ( $\mathbf{F i g . 6 F}$ ).

Licorice (Glycyrrhiza glabra, Fabaceae) also was reported to contain compounds with serotonergic effects. Glabridin, 4'-O-methylglabridin, and glabrene ( $\bullet$ Fig. 6C) from Glycyrrhiza glabra inhibited the reuptake of radioactive serotonin in HEK-293 cells at $50 \mu \mathrm{M}$, with glabridin having a dose-dependent effect [173].

Dong quai (Angelica sinensis, Apiaceae) has been shown to have serotonin-like activity in the $5-\mathrm{HT}_{7}$ serotonin receptor binding assay, and its most active compound was $p$-hydroxyphenethyl trans-ferulate $\left(\mathrm{IC}_{50}=47.6 \mu \mathrm{M}\right)(\odot$ Fig. 6D) [174]. Deng et al. [174] reported that $p$-hydroxyphenethyl trans-ferulate, $Z$-butylidenephtalide, 11(S), 16(R)-dihydroxyoctadeca-9Z,17-diene, 8-hydroxy-1-methoxy-, Z-9-heptadecene-4,6-diyn-3-one, and imperatorin ( Fig.6D) isolated from the methanolic extract of dong quai weakly bound to the $5-\mathrm{HT}_{7}$ receptor. These data suggest that dong quai might have serotonergic activity.

\section{Summary of Clinical Trial Data of Botanical Supplements Used for Menopausal Symptoms $\nabla$}

Clinical evidence supporting the efficacy of most botanicals for alleviating vasomotor symptoms is sparse $[169,175]$. A randomized, four-arm, double-blind clinical trial of standardized black cohosh extract, red clover extract, placebo, and equine estrogen plus progestin showed that these remedies did not significantly alter the status of vasomotor symptoms compared to placebo [169]. On the other hand, in a meta-analysis performed on evaluating the efficacy of black cohosh, 6 of 9 eligible clinical trials showed a significant effect in the black cohosh group compared to the placebo group [170]. Black cohosh treatment improved vasomotor symptoms, overall by $26 \%$. However, there was a significant discrepancy between the reviewed trials. Similarly, a recent double-blind, placebo-controlled multicenter clinical study using an isopropanolic extract of black cohosh for managing menopausal symptoms showed some efficacy and no toxicity [176]. A double-blind, randomized, controlled trial of dietary soy consumption by menopausal women showed a significant improvement in reducing somatic symptoms including hot flashes com- pared to placebo [177]. However, a meta-analysis by Bolanos et al. [178] demonstrated that due to the huge heterogeneity in the studies, having a unified conclusion was not possible, although the overall results had a tendency in favor of soy efficacy. In a single-center, randomized, placebo-controlled, double-blind study, Levis et al. [179] observed that a larger proportion of the women in the soy group experienced hot flashes and constipation compared to the control group, and that there were no significant differences between groups in other outcomes. The North American Menopause Society (October 2010) [180] concluded that while different studies showed mixed efficacy results, soy-based isoflavones seem to be weakly effective in relieving menopausal symptoms, and the effects might be more pronounced in supplements with higher genistein content or increased S-equol. There are many more clinical trials that showed mixed results about the efficacy of botanicals in menopausal women [181-184]. While these equivocal data could be due to the study settings, botanical sources, standardization issues, dosing, and symptom evaluation system, laboratory and preclinical studies have shown some promising effects and clear mechanisms of action for some botanicals supporting their potential for managing vasomotor symptoms.

\section{Conclusions}

$\nabla$

While HT remains the gold standard for managing vasomotor symptoms, increasing numbers of menopausal women seek alternative nonhormonal remedies including botanicals. The mixed results of different trials might indicate that botanicals can be helpful for some women, especially those with contraindications for HT. Current data are insufficient to suggest botanicals as proven remedies for menopausal symptoms, and additional clinical trials are necessary. Further characterization of well-defined herbal extracts is crucial to better understand their effects and predict the safety issues that might arise due to their increased intake. Such information would be helpful for health-care providers when addressing the menopausal problems of patients, since women continue taking botanicals for managing menopausal symptoms. Finally, understanding the mechanism of action, could also direct researchers to find naturally occurring active components with the potential of becoming effective medications in the future with the desired safety profile for alleviation of menopausal symptoms.

\section{Acknowledgements}

$\nabla$

Support for this work was through Grant P50 AT00155, which was provided to the UIC/NIH Center for Botanical Dietary Supplements Research by the Office of Dietary Supplements (ODS/NIH) and the National Center for Complementary and Alternative Medicine (NCCAM/NIH).

\section{Conflict of Interest \\ $\nabla$}

The authors have no conflict of interest regarding the materials discussed in this manuscript. 
References

1 Roush K. Managing menopausal symptoms. Am J Nurs 2012; 112: 28 35

2 Ortmann O, Lattrich C. The treatment of climacteric symptoms. Dtsch Arztebl Int 2012; 109: 316-323

3 Aidelsburger P, Schauer S, Grabein K, Wasem J. Alternative methods for the treatment of post-menopausal troubles. GMS Health Technol Assess 2012; DOI: 10.3205/hta000101

4 Rossouw JE, Anderson GL, Prentice RL, LaCroix AZ, Kooperberg C, Stefanick ML, Jackson RD, Beresford SA, Howard BV, Johnson KC, Kotchen JM, Ockene J. Risks and benefits of estrogen plus progestin in healthy postmenopausal women: principal results from the Women's Health Initiative randomized controlled trial. JAMA 2002; 288: 321-333

5 Geller SE, Studee L. Botanical and dietary supplements for menopausal symptoms: what works, what does not. J Womens Health 2005; 14: 634-649

6 Pitkin J. Alternative and complementary therapies for the menopause. Menopause Int 2012; 18: 20-27

7 Wang XY, Nie GN, Yang HY, Zong $L L$. Chinese medicine for menopausal syndrome: current status, problems and strategies. Chin J Integr Med 2011; 17: 889-892

8 Taechakraichana N, Jaisamrarn U, Panyakhamlerd K, Chaikittisilpa S, Limpaphayom KK. Climacteric: concept, consequence and care. J Med Assoc Thai 2002; 85 (Suppl. 1): S1-S15

9 Overk CR, Yao P, Chadwick LR, Nikolic D, Sun Y, Cuendet MA, Deng Y, Hedayat AS, Pauli GF, Farnsworth NR, van Breemen RB, Bolton JL. Comparison of the in vitro estrogenic activities of compounds from hops (Humulus lupulus) and red clover (Trifolium pratense). J Agric Food Chem 2005; 53: 6246-6253

10 Al-Nakkash L, Markus B, Batia L, Prozialeck WC, Broderick TL. Genistein induces estrogen-like effects in ovariectomized rats but fails to increase cardiac GLUT4 and oxidative stress. J Med Food 2010; 13: 1369-1375

11 Toh MF, Sohn J, Chen SN, Yao P, Bolton JL, Burdette JE. Biological characterization of non-steroidal progestins from botanicals used for women's health. Steroids 2012; 77: 765-773

12 Powell SL, Godecke T, Nikolic D, Chen SN, Ahn S, Dietz B, Farnsworth NR, van Breemen RB, Lankin DC, Pauli GF, Bolton JL. In vitro serotonergic activity of black cohosh and identification of N(omega)-methylserotonin as a potential active constituent. J Agric Food Chem 2008; 56: 1171811726

13 Chueh FS, Chang CP, Chio CC, Lin MT. Puerarin acts through brain serotonergic mechanisms to induce thermal effects. J Pharmacol Sci 2004; 96: 420-427

14 Ames MS, Hong S, Lee HR, Fields HW, Johnston WM, Kim DG. Estrogen deficiency increases variability of tissue mineral density of alveolar bone surrounding teeth. Arch Oral Biol 2010; 55: 599-605

15 Pelekanou V, Leclercq $G$. Recent insights into the effect of natural and environmental estrogens on mammary development and carcinogenesis. Int J Dev Biol 2011; 55: 869-878

16 Pastore MB, Jobe SO, Ramadoss J, Magness RR. Estrogen receptor-alpha and estrogen receptor-beta in the uterine vascular endothelium during pregnancy: functional implications for regulating uterine blood flow. Semin Reprod Med 2012; 30: 46-61

17 Nofer JR. Estrogens and atherosclerosis: insights from animal models and cell systems. J Mol Endocrinol 2012; 48: R13-R29

18 Krishnan V, Heath $\mathrm{H}$, Bryant HU. Mechanism of action of estrogens and selective estrogen receptor modulators. Vitam Horm 2000; 60: 123147

19 O'Donnell E, Harvey PJ, Goodman JM, De Souza MJ. Long-term estrogen deficiency lowers regional blood flow, resting systolic blood pressure, and heart rate in exercising premenopausal women. Am J Physiol Endocrinol Metab 2007; 292: E1401-E1409

20 Nilsson S, Makela S, Treuter E, Tujague M, Thomsen J, Andersson G, Enmark E, Pettersson K, Warner M, Gustafsson JA. Mechanisms of estrogen action. Physiol Rev 2001; 81: 1535-1565

21 Ellmann S, Sticht H, Thiel F, Beckmann MW, Strick R, Strissel PL. Estrogen and progesterone receptors: from molecular structures to clinical targets. Cell Mol Life Sci 2009; 66: 2405-2426

22 Bjornstrom L, Sjoberg M. Mechanisms of estrogen receptor signaling: convergence of genomic and nongenomic actions on target genes. Mol Endocrinol 2005; 19: 833-842

23 O'Lone R, Frith MC, Karlsson EK, Hansen U. Genomic targets of nuclear estrogen receptors. Mol Endocrinol 2004; 18: 1859-1875
24 Song $R X$, Santen RJ. Membrane initiated estrogen signaling in breast cancer. Biol Reprod 2006; 75: 9-16

25 Filardo EJ. Epidermal growth factor receptor (EGFR) transactivation by estrogen via the G-protein-coupled receptor, GPR30: a novel signaling pathway with potential significance for breast cancer. J Steroid Biochem Mol Biol 2002; 80: 231-238

26 Prossnitz ER, Sklar LA, Oprea TI, Arterburn JB. GPR30: a novel therapeutic target in estrogen-related disease. Trends Pharmacol Sci 2008; 29: $116-123$

27 Shanle EK, Xu W. Selectively targeting estrogen receptors for cancer treatment. Adv Drug Deliv Rev 2010; 62: 1265-1276

28 Thomas C, Gustafsson JA. The different roles of ER subtypes in cancer biology and therapy. Nat Rev Cancer 2011; 11: 597-608

29 Deroo BJ, Buensuceso AV. Minireview: Estrogen receptor-beta: mechanistic insights from recent studies. Mol Endocrinol 2010; 24: 17031714

30 Kuiper GG, Lemmen JG, Carlsson B, Corton JC, Safe SH, van der Saag PT, van der Burg B, Gustafsson JA. Interaction of estrogenic chemicals and phytoestrogens with estrogen receptor beta. Endocrinology 1998; 139: 4252-4263

31 Pike MC, Ross RK. Progestins and menopause: epidemiological studies of risks of endometrial and breast cancer. Steroids 2000; 65: 659-664

32 Dave B, Wynne R, Su Y, Korourian S, Chang JC, Simmen RC. Enhanced mammary progesterone receptor-A isoform activity in the promotion of mammary tumor progression by dietary soy in rats. Nutr Cancer 2010; 62: 774-782

33 Scarpin KM, Graham JD, Mote PA, Clarke CL. Progesterone action in human tissues: regulation by progesterone receptor (PR) isoform expression, nuclear positioning and coregulator expression. Nucl Recept Signal 2009; DOI: $10.1621 /$ nrs.07009

34 Gronemeyer H, Meyer ME, Bocquel MT, Kastner P, Turcotte B, Chambon P. Progestin receptors: isoforms and antihormone action. J Steroid Biochem Mol Biol 1991; 40: 271-278

35 Aupperlee MD, Haslam SZ. Differential hormonal regulation and function of progesterone receptor isoforms in normal adult mouse mammary gland. Endocrinology 2007; 148: 2290-2300

36 Harduf H, Goldman S, Shalev E. Progesterone receptor A and c-Met mediates spheroids-endometrium attachment. Reprod Biol Endocrinol 2009; DOI: 10.1186/1477-7827-1187-1114

37 Kariagina A, Aupperlee MD, Haslam SZ. Progesterone receptor isoforms and proliferation in the rat mammary gland during development. Endocrinology 2007; 148: 2723-2736

38 Shanafelt TD, Barton DL, Adjei AA, Loprinzi CL. Pathophysiology and treatment of hot flashes. Mayo Clin Proc 2002; 77: 1207-1218

39 Pearlstein T. Psychotropic medications and other non-hormonal treatments for premenstrual disorders. Menopause Int 2012; 18: 60-64

40 Nachtigall LE. Therapy: nonhormonal treatment of hot flashes - a viable alternative? Nat Rev Endocrinol 2010; 6: 66-67

41 Kintscher $U$. Reuptake inhibitors of dopamine, noradrenaline, and serotonin. Handb Exp Pharmacol 2012; 209: 339-347

42 Taylor M. Complementary and alternative medicine preparations used to treat symptoms of menopause. Menopausal Med 2012; 20: S1-S8

43 Tsunoda N, Pomeroy S, Nestel P. Absorption in humans of isoflavones from soy and red clover is similar. J Nutr 2002; 132: 2199-2201

44 Oerter Klein K, Janfaza M, Wong JA, Chang RJ. Estrogen bioactivity in foti and other herbs used for their estrogen-like effects as determined by a recombinant cell bioassay. J Clin Endocrinol Metab 2003; 88: 40774079

45 Nielsen IL, Williamson G. Review of the factors affecting bioavailability of soy isoflavones in humans. Nutr Cancer 2007; 57: 1-10

46 Mortensen A, Kulling SE, Schwartz H, Rowland I, Ruefer CE, Rimbach G, Cassidy A, Magee P, Millar J, Hall WL, Kramer Birkved F, Sorensen IK, Sontag $G$. Analytical and compositional aspects of isoflavones in food and their biological effects. Mol Nutr Food Res 2009; 53: S266-S309

47 McCarty MF. Isoflavones made simple - genistein's agonist activity for the beta-type estrogen receptor mediates their health benefits. Med Hypotheses 2006; 66: 1093-1114

48 Harris DM, Besselink E, Henning SM, Go VL, Heber D. Phytoestrogens induce differential estrogen receptor alpha- or beta-mediated responses in transfected breast cancer cells. Exp Biol Med 2005; 230: 558-568

49 Zhao L, Mao Z, Brinton RD. A select combination of clinically relevant phytoestrogens enhances estrogen receptor beta-binding selectivity and neuroprotective activities in vitro and in vivo. Endocrinology 2009; 150: 770-783 
50 Muthyala RS, Ju YH, Sheng S, Williams LD, Doerge DR, Katzenellenbogen $B S$, Helferich WG, Katzenellenbogen JA. Equol, a natural estrogenic metabolite from soy isoflavones: convenient preparation and resolution of R- and S-equols and their differing binding and biological activity through estrogen receptors alpha and beta. Bioorg Med Chem 2004; 12: 1559-1567

51 Jackson RL, Greiwe JS, Schwen RJ. Emerging evidence of the health benefits of S-equol, an estrogen receptor beta agonist. Nutr Rev 2011; 69: 432-448

52 Yuan JP, Wang JH, Liu X. Metabolism of dietary soy isoflavones to equol by human intestinal microflora-implications for health. Mol Nutr Food Res 2007; 51: 765-781

53 Atkinson C, Frankenfeld CL, Lampe JW. Gut bacterial metabolism of the soy isoflavone daidzein: exploring the relevance to human health. Exp Biol Med 2005; 230: 155-170

54 Shor D, Sathyapalan T, Atkin SL, Thatcher NJ. Does equol production determine soy endocrine effects? Eur J Nutr 2012; 51: 389-398

55 Zhang EJ, $\mathrm{Ng} \mathrm{KM}$, Luo KQ. Extraction and purification of isoflavones from soybeans and characterization of their estrogenic activities. J Agric Food Chem 2007; 55: 6940-6950

56 Schmitt E, Dekant W, Stopper H. Assaying the estrogenicity of phytoestrogens in cells of different estrogen sensitive tissues. Toxicol In Vitro 2001; 15: 433-439

57 Onoda A, Ueno T, Uchiyama S, Hayashi S, Kato K, Wake N. Effects of Sequol and natural S-equol supplement (SE5-OH) on the growth of MCF-7 in vitro and as tumors implanted into ovariectomized athymic mice. Food Chem Toxicol 2011; 49: 2279-2284

$58 \mathrm{Ju}$ YH, Fultz J, Allred KF, Doerge DR, Helferich WG. Effects of dietary daidzein and its metabolite, equol, at physiological concentrations on the growth of estrogen-dependent human breast cancer (MCF-7) tumors implanted in ovariectomized athymic mice. Carcinogenesis 2006; 27: 856-863

59 Hwang CS, Kwak HS, Lim HJ, Lee SH, Kang YS, Choe TB, Hur HG, Han KO. Isoflavone metabolites and their in vitro dual functions: they can act as an estrogenic agonist or antagonist depending on the estrogen concentration. J Steroid Biochem Mol Biol 2006; 101: 246-253

60 Sakamoto T, Horiguchi H, Oguma E, Kayama F. Effects of diverse dietary phytoestrogens on cell growth, cell cycle and apoptosis in estrogen-receptor-positive breast cancer cells. J Nutr Biochem 2010; 21: 856-864

61 Sathyamoorthy N, Wang TT. Differential effects of dietary phyto-oestrogens daidzein and equol on human breast cancer MCF-7 cells. Eur J Cancer 1997; 33: 2384-2389

62 Chang EC, Charn TH, Park SH, Helferich WG, Komm B, Katzenellenbogen $J A$, Katzenellenbogen BS. Estrogen receptors alpha and beta as determinants of gene expression: influence of ligand, dose, and chromatin binding. Mol Endocrinol 2008; 22: 1032-1043

63 van Meeuwen JA, Korthagen N, de Jong PC, Piersma AH, van den Berg M. (Anti)estrogenic effects of phytochemicals on human primary mammary fibroblasts, MCF-7 cells and their co-culture. Toxicol Appl Pharmacol 2007; 221: 372-383

64 Wober J, Weisswange I, Vollmer G. Stimulation of alkaline phosphatase activity in Ishikawa cells induced by various phytoestrogens and synthetic estrogens. J Steroid Biochem Mol Biol 2002; 83: 227-233

65 Kayisli UA, Aksu CA, Berkkanoglu M, Arici A. Estrogenicity of isoflavones on human endometrial stromal and glandular cells. J Clin Endocrinol Metab 2002; 87: 5539-5544

66 Cimafranca MA, Davila J, Ekman GC, Andrews RN, Neese SL, Peretz J, Woodling KA, Helferich WG, Sarkar J, Flaws JA, Schantz SL, Doerge DR, Cooke PS. Acute and chronic effects of oral genistein administration in neonatal mice. Biol Reprod 2010; 83: 114-121

67 Legette LL, Martin BR, Shahnazari M, Lee WH, Helferich WG, Qian J, Waters DJ, Arabshahi A, Barnes S, Welch J, Bostwick DG, Weaver CM. Supplemental dietary racemic equol has modest benefits to bone but has mild uterotropic activity in ovariectomized rats. J Nutr 2009; 139 : 1908-1913

68 Boue SM, Wiese TE, Nehls S, Burow ME, Elliott S, Carter-Wientjes CH, Shih $B Y$, McLachlan JA, Cleveland TE. Evaluation of the estrogenic effects of legume extracts containing phytoestrogens. J Agric Food Chem 2003; 51: 2193-2199

69 de Lima Toccafondo Vieira M, Duarte RF, Campos LM, Nunan Ede A. Comparison of the estrogenic potencies of standardized soy extracts by immature rat uterotrophic bioassay. Phytomedicine 2008; 15: 31-37

70 Allred CD, Allred KF, Ju YH, Goeppinger TS, Doerge DR, Helferich WG. Soy processing influences growth of estrogen-dependent breast cancer tumors. Carcinogenesis 2004; 25: 1649-1657
71 Hilakivi-Clarke L, Andrade JE, Helferich W. Is soy consumption good or bad for the breast? J Nutr 2010; 140: 2326S-2334S

72 Dietz BM, Bolton JL. Anti-inflammatory botanical dietary supplements for women's health: role in breast cancer prevention?, In: Kong T, editor. Inflammation and cancer: mechanisms and dietary approaches for cancer prevention. Boca Raton: CRC Press; in press

73 Kuiper GG, Carlsson B, Grandien K, Enmark E, Haggblad J, Nilsson S, Gustafsson JA. Comparison of the ligand binding specificity and transcript tissue distribution of estrogen receptors alpha and beta. Endocrinology 1997; 138: 863-870

74 Piersen CE, Booth NL, Sun Y, Liang W, Burdette JE, van Breemen RB, Geller SE, Gu C, Banuvar S, Shulman LP, Bolton JL, Farnsworth NR. Chemical and biological characterization and clinical evaluation of botanical dietary supplements: a phase I red clover extract as a model. Curr Med Chem 2004; 11: 1361-1374

75 Booth NL, Overk CR, Yao P, Burdette JE, Nikolic D, Chen SN, Bolton JL, van Breemen RB, Pauli GF, Farnsworth NR. The chemical and biologic profile of a red clover (Trifolium pratense L.) phase II clinical extract. J Altern Complement Med 2006; 12: 133-139

76 Hsu JT, Hung HC, Chen CJ, Hsu WL, Ying C. Effects of the dietary phytoestrogen biochanin A on cell growth in the mammary carcinoma cell line MCF-7. J Nutr Biochem 1999; 10: 510-517

77 Markiewicz L, Garey J, Adlercreutz H, Gurpide E. In vitro bioassays of non-steroidal phytoestrogens. J Steroid Biochem Mol Biol 1993; 45: 399-405

78 Fokialakis N, Alexi X, Aligiannis N, Siriani D, Meligova AK, Pratsinis $\mathrm{H}, \mathrm{Mi}$ takou S, Alexis MN. Ester and carbamate ester derivatives of Biochanin A: synthesis and in vitro evaluation of estrogenic and antiproliferative activities. Bioorg Med Chem 2012; 20: 2962-2970

79 Halabalaki M, Alexi X, Aligiannis $N$, Lambrinidis $G$, Pratsinis $H$, Florentin I, Mitakou S, Mikros E, Skaltsounis AL, Alexis MN. Estrogenic activity of isoflavonoids from Onobrychis ebenoides. Planta Med 2006; 72: 488493

80 Zoechling A, Reiter E, Eder R, Wendelin S, Liebner F, Jungbauer A. The flavonoid kaempferol is responsible for the majority of estrogenic activity in red wine. Am J Enol Viticult 2009; 60: 223-232

81 Burdette JE, Liu J, Lantvit D, Lim E, Booth N, Bhat KP, Hedayat S, Van Breemen RB, Constantinou AI, Pezzuto JM, Farnsworth NR, Bolton JL. Trifolium pratense (red clover) exhibits estrogenic effects in vivo in ovariectomized Sprague-Dawley rats. J Nutr 2002; 132: 27-30

82 Overk CR, Guo J, Chadwick LR, Lantvit DD, Minassi A, Appendino G, Chen $S N$, Lankin DC, Farnsworth NR, Pauli GF, van Breemen RB, Bolton JL. In vivo estrogenic comparisons of Trifolium pratense (red clover), Humulus lupulus (hops), and the pure compounds isoxanthohumol and 8prenylnaringenin. Chem Biol Interact 2008; 176: 30-39

83 Zhang D, Ren Y, Dai S, Liu W, Li G. [Isoflavones from vines of Pueraria lobata]. Zhongguo Zhong Yao Za Zhi 2009; 34: 3217-3220

84 Delmonte P, Perry J, Rader JI. Determination of isoflavones in dietary supplements containing soy, Red Clover and kudzu: extraction followed by basic or acid hydrolysis. J Chromatogr A 2006; 1107: 59-69

85 Park EK, Shin J, Bae EA, Lee YC, Kim DH. Intestinal bacteria activate estrogenic effect of main constituents puerarin and daidzin of Pueraria thunbergiana. Biol Pharm Bull 2006; 29: 2432-2435

86 Nakamura K, Nishihata T, Jin JS, Ma CM, Komatsu K, Iwashima M, Hattori $M$. The C-glucosyl bond of puerarin was cleaved hydrolytically by a human intestinal bacterium strain PUE to yield its aglycone daidzein and an intact glucose. Chem Pharm Bull 2011; 59: 23-27

87 Cherdshewasart W, Traisup V, Picha P. Determination of the estrogenic activity of wild phytoestrogen-rich Pueraria mirifica by MCF-7 proliferation assay. J Reprod Dev 2008; 54: 63-67

88 Cherdshewasart W, Cheewasopit W, Picha P. The differential anti-proliferation effect of white (Pueraria mirifica), red (Butea superba), and black (Mucuna collettii) Kwao Krua plants on the growth of MCF-7 cells. J Ethnopharmacol 2004; 93: 255-260

89 Matsumura A, Ghosh A, Pope GS, Darbre PD. Comparative study of oestrogenic properties of eight phytoestrogens in MCF7 human breast cancer cells. J Steroid Biochem Mol Biol 2005; 94: 431-443

90 Boonchird C, Mahapanichkul T, Cherdshewasart W. Differential binding with ERalpha and ERbeta of the phytoestrogen-rich plant Pueraria mirifica. Braz J Med Biol Res 2010; 43: 195-200

91 Gomuttapong S, Pewphong R, Choeisiri S, Jaroenporn S, Malaivijitnond S. Testing of the estrogenic activity and toxicity of Stephania venosa herb in ovariectomized rats. Toxicol Mech Methods 2012; 22: 445-457 
92 Malaivijitnond S, Chansri K, Kijkuokul P, Urasopon N, Cherdshewasart $W$. Using vaginal cytology to assess the estrogenic activity of phytoestrogen-rich herb. J Ethnopharmacol 2006; 107: 354-360

93 Sookvanichsilp N, Soonthornchareonnon N, Boonleang C. Estrogenic activity of the dichloromethane extract from Pueraria mirifica. Fitoterapia 2008; 79: 509-514

94 Urasopon N, Hamada Y, Cherdshewasart W, Malaivijitnond S. Preventive effects of Pueraria mirifica on bone loss in ovariectomized rats. Maturitas 2008; 59: 137-148

95 Malaivijitnond S, Tungmunnithum D, Gittarasanee S, Kawin K, Limjunyawong $N$. Puerarin exhibits weak estrogenic activity in female rats. Fitoterapia 2010; 81: 569-576

96 Malaivijitnond S. Medical applications of phytoestrogens from the Thai herb Pueraria mirifica. Front Med 2012; 6: 8-21

97 Salter S, Brownie S. Treating primary insomnia - the efficacy of valerian and hops. Aust Fam Physician 2010; 39: 433-437

98 Blumenthal M, German Federal Institute for Drugs and Medical Devices. Commission E. Herbal medicine:expanded Commission E monographs, 1st edition. Newton, MA: Integrative Medicine Communications; 2000: 519

99 Liu J, Burdette JE, Xu H, Gu C, van Breemen RB, Bhat KP, Booth N, Constantinou AI, Pezzuto JM, Fong HH, Farnsworth NR, Bolton JL. Evaluation of estrogenic activity of plant extracts for the potential treatment of menopausal symptoms. J Agric Food Chem 2001; 49: 2472-2479

100 Milligan SR, Kalita JC, Pocock V, Van De Kauter V, Stevens JF, Deinzer ML, Rong H, De Keukeleire D. The endocrine activities of 8-prenylnaringenin and related hop (Humulus lupulus L.) flavonoids. J Clin Endocrinol Metab 2000; 85: 4912-4915

101 Roelens F, Heldring N, Dhooge W, Bengtsson M, Comhaire F, Gustafsson $J A$, Treuter E, De Keukeleire D. Subtle side-chain modifications of the hop phytoestrogen 8-prenylnaringenin result in distinct agonist/antagonist activity profiles for estrogen receptors alpha and beta. J Med Chem 2006; 49: 7357-7365

102 Bovee TFH, Helsdingen RJR, Rietjens I, Keijer J, Hoogenboom R. Rapid yeast estrogen bioassays stably expressing human estrogen receptors alpha and beta, and green fluorescent protein: a comparison of different compounds with both receptor types. J Steroid Biochem Mol Biol 2004; 91: 99-109

103 Milligan S, Kalita J, Pocock V, Heyerick A, De Cooman L, Rong H, De Keukeleire $D$. Oestrogenic activity of the hop phyto-oestrogen, 8-prenylnaringenin. Reproduction 2002; 123: 235-242

104 Diel P, Thomae RB, Caldarelli A, Zierau O, Kolba S, Schmidt S, Schwab P, Metz P, Vollmer G. Regulation of gene expression by 8-prenylnaringenin in uterus and liver of Wistar rats. Planta Med 2004; 70: 39-44

105 Bolca S, Li J, Nikolic D, Roche N, Blondeel P, Possemiers S, De Keukeleire $D$, Bracke M, Heyerick A, van Breemen RB, Depypere H. Disposition of hop prenylflavonoids in human breast tissue. Mol Nutr Food Res 2010; 54: S284-S294

106 Possemiers S, Rabot S, Espin JC, Bruneau A, Philippe C, Gonzalez-Sarrias A, Heyerick A, Tomas-Barberan FA, De Keukeleire D, Verstraete W. Eubacterium limosum activates isoxanthohumol from hops (Humulus lupulus $\mathrm{L}$.) into the potent phytoestrogen 8-prenylnaringenin in vitro and in rat intestine. J Nutr 2008; 138: 1310-1316

107 Bolca S, Possemiers S, Herregat A, Huybrechts I, Heyerick A, De Vriese S, Verbruggen M, Depypere H, De Keukeleire D, Bracke M, De Henauw S, Verstraete $W$, Van de Wiele T. Microbial and dietary factors are associated with the equol producer phenotype in healthy postmenopausal women. J Nutr 2007; 137: 2242-2246

108 Possemiers S, Bolca S, Grootaert C, Heyerick A, Decroos K, Dhooge W, De Keukeleire D, Rabot S, Verstraete $W$, Van de Wiele T. The prenylflavonoid isoxanthohumol from hops (Humulus lupulus $\mathrm{L}$.) is activated into the potent phytoestrogen 8-prenylnaringenin in vitro and in the human intestine. J Nutr 2006; 136: 1862-1867

109 Possemiers S, Heyerick A, Robbens V, De Keukeleire D, Verstraete W. Activation of proestrogens from hops (Humulus lupulus L.) by intestinal microbiota; conversion of isoxanthohumol into 8-prenylnaringenin. J Agric Food Chem 2005; 53: 6281-6288

110 Asl MN, Hosseinzadeh H. Review of pharmacological effects of Glycyrrhiza sp. and its bioactive compounds. Phytother Res 2008; 22: 709724

111 Dong S, Inoue A, Zhu Y, Tanji M, Kiyama R. Activation of rapid signaling pathways and the subsequent transcriptional regulation for the proliferation of breast cancer MCF-7 cells by the treatment with an extract of Glycyrrhiza glabra root. Food Chem Toxicol 2007; 45: 24702478
112 Simons R, Vincken JP, Mol LA, The SA, Bovee TF, Luijendijk TJ, Verbruggen $M A$, Gruppen H. Agonistic and antagonistic estrogens in licorice root (Glycyrrhiza glabra). Anal Bioanal Chem 2011; 401: 305-313

113 Tamir S, Eizenberg M, Somjen D, Stern N, Shelach R, Kaye A, Vaya J. Estrogenic and antiproliferative properties of glabridin from licorice in human breast cancer cells. Cancer Res 2000; 60: 5704-5709

114 Somjen D, Katzburg S, Vaya J, Kaye AM, Hendel D, Posner GH, Tamir S. Estrogenic activity of glabridin and glabrene from licorice roots on human osteoblasts and prepubertal rat skeletal tissues. J Steroid Biochem Mol Biol 2004; 91: 241-246

115 Somjen D, Knoll E, Vaya J, Stern N, Tamir S. Estrogen-like activity of licorice root constituents: glabridin and glabrene, in vascular tissues in vitro and in vivo. J Steroid Biochem Mol Biol 2004; 91: 147-155

116 Kang SC, Lee CM, Choi H, Lee JH, Oh JS, Kwak JH, Zee OP. Evaluation of oriental medicinal herbs for estrogenic and antiproliferative activities. Phytother Res 2006; 20: 1017-1019

117 Kim IG, Kang SC, Kim KC, Choung ES, Zee OP. Screening of estrogenic and antiestrogenic activities from medicinal plants. Environ Toxicol Pharmacol 2008; 25: 75-82

118 Hu C, Liu H, Du J, Mo B, Qi H, Wang X, Ye S, Li Z. Estrogenic activities of extracts of Chinese licorice (Glycyrrhiza uralensis) root in MCF-7 breast cancer cells. J Steroid Biochem Mol Biol 2009; 113: 209-216

119 Amato P, Christophe S, Mellon PL. Estrogenic activity of herbs commonly used as remedies for menopausal symptoms. Menopause 2002; 9: 145-150

120 Kondo K, Shiba M, Nakamura R, Morota T, Shoyama Y. Constituent properties of licorices derived from Glycyrrhiza uralensis, G. glabra, or G. inflata identified by genetic information. Biol Pharm Bull 2007; 30: 1271-1277

121 Mersereau JE, Levy N, Staub RE, Baggett S, Zogovic T, Chow S, Ricke WA, Tagliaferri M, Cohen I, Bjeldanes LF, Leitman DC. Liquiritigenin is a plant-derived highly selective estrogen receptor beta agonist. Mol Cell Endocrinol 2008; 283: 49-57

122 Maggiolini M, Statti G, Vivacqua A, Gabriele S, Rago V, Loizzo M, Menichini F, Amdo S. Estrogenic and antiproliferative activities of isoliquiritigenin in MCF7 breast cancer cells. J Steroid Biochem Mol Biol 2002; 82: $315-322$

123 Zhang CZ, Wang SX, Zhang Y, Chen JP, Liang XM. In vitro estrogenic activities of Chinese medicinal plants traditionally used for the management of menopausal symptoms. J Ethnopharmacol 2005; 98: 295300

124 Usui T, Ikeda Y, Tagami T, Matsuda K, Moriyama K, Yamada K, Kuzuya $H$, Kohno S, Shimatsu A. The phytochemical lindleyin, isolated from Rhei rhizoma, mediates hormonal effects through estrogen receptors. J Endocrinol 2002; 175: 289-296

125 Wober J, Moller F, Richter T, Unger C, Weigt C, Jandausch A, Zierau O, Rettenberger R, Kaszkin-Bettag M, Vollmer G. Activation of estrogen receptor-beta by a special extract of Rheum rhaponticum (ERr 731), its aglycones and structurally related compounds. J Steroid Biochem Mol Biol 2007; 107: 191-201

126 Moller F, Zierau O, Jandausch A, Rettenberger R, Kaszkin-Bettag M, Vollmer $G$. Subtype-specific activation of estrogen receptors by a special extract of Rheum rhaponticum (ERr 731), its aglycones and structurally related compounds in U2OS human osteosarcoma cells. Phytomedicine 2007; 14: 716-726

127 Papke A, Kretzschmar G, Zierau O, Kaszkin-Bettag M, Vollmer G. Effects of the special extract ERr 731 from Rheum rhaponticum on estrogenregulated targets in the uterotrophy model of ovariectomized rats. J Steroid Biochem Mol Biol 2009; 117: 176-184

128 Keiler AM, Papke A, Kretzschmar G, Zierau O, Vollmer G. Long-term effects of the rhapontic rhubarb extract ERr 731(R) on estrogen-regulated targets in the uterus and on the bone in ovariectomized rats. J Steroid Biochem Mol Biol 2012; 128: 62-68

129 Vollmer G, Papke A, Zierau 0 . Treatment of menopausal symptoms by an extract from the roots of rhapontic rhubarb: the role of estrogen receptors. Chin Med 2010; 5: 7-10

130 Park MK, Kwon HY, Ahn WS, Bae S, Rhyu MR, Lee Y. Estrogen activities and the cellular effects of natural progesterone from wild yam extract in mcf-7 human breast cancer cells. Am J Chin Med 2009; 37: 159167

131 Cheng WY, Kuo YH, Huang CJ. Isolation and identification of novel estrogenic compounds in yam tuber (Dioscorea alata Cv. Tainung No. 2). J Agric Food Chem 2007; 55: 7350-7358 
132 Wu WH, Liu LY, Chung CJ, Jou HJ, Wang TA. Estrogenic effect of yam ingestion in healthy postmenopausal women. J Am Coll Nutr 2005; 24: 235-243

133 Mirkin G. Estrogen in yams. JAMA 1991; 265: 912

134 Aradhana, Rao AR, Kale RK. Diosgenin - a growth stimulator of mammary gland of ovariectomized mouse. Indian J Exp Biol 1992; 30 : 367-370

135 Liu J, Burdette JE, Sun Y, Deng S, Schlecht SM, Zheng W, Nikolic D, Mahady G, van Breemen RB, Fong HH, Pezzuto JM, Bolton JL, Farnsworth $N R$. Isolation of linoleic acid as an estrogenic compound from the fruits of Vitex agnus-castus L. (chaste-berry). Phytomedicine 2004; 11: $18-23$

136 Ibrahim NA, Shalaby AS, Farag RS, Elbaroty GS, Nofal SM, Hassan EM. Gynecological efficacy and chemical investigation of Vitex agnus-castus L. fruits growing in Egypt. Nat Prod Res 2008; 22: 537-546

137 Jarry H, Spengler B, Porzel A, Schmidt J, Wuttke W, Christoffel V. Evidence for estrogen receptor beta-selective activity of Vitex agnus-castus and isolated flavones. Planta Med 2003; 69: 945-947

138 Choi SY, Ha TY, Ahn JY, Kim SR, Kang KS, Hwang IK, Kim S. Estrogenic activities of isoflavones and flavones and their structure-activity relationships. Planta Med 2008; 74: 25-32

139 Jarry $H$, Spengler B, Wuttke W, Christoffel V. In vitro assays for bioactivity-guided isolation of endocrine active compounds in Vitex agnuscastus. Maturitas 2006; 55: S26-S36

140 Hu Y, Zhang QY, Hou TT, Xin HL, Zheng HC, Rahman K, Qin LP. Estrogenlike activities in Vitex species from China determined by a cell based proliferation assay. Pharmazie 2007; 62: 872-875

141 Hu Y, Hou TT, Xin HL, Zhang QY, Zheng HC, Rahman K, Qin LP. Estrogenlike activity of volatile components from Vitex rotundifolia $\mathrm{L}$. Indian J Med Res 2007; 126: 68-72

142 Hu Y, Hou TT, Zhang QY, Xin HL, Zheng HC, Rahman K, Qin LP. Evaluation of the estrogenic activity of the constituents in the fruits of Vitex rotundifolia $\mathrm{L}$. for the potential treatment of premenstrual syndrome. J Pharm Pharmacol 2007; 59: 1307-1312

143 Piersen CE. Phytoestrogens in botanical dietary supplements: implications for cancer. Integr Cancer Ther 2003; 2: 120-138

144 Circosta C, Pasquale RD, Palumbo DR, Samperi S, Occhiuto F. Estrogenic activity of standardized extract of Angelica sinensis. Phytother Res 2006; 20: 665-669

145 Zhan JY, Zheng KY, Zhu KY, Bi CW, Zhang WL, Du CY, Fu Q, Dong TT, Choi $R C$, Tsim KW, Lau DT. Chemical and biological assessment of Angelicae Sinensis Radix after processing with wine: an orthogonal array design to reveal the optimized conditions. J Agric Food Chem 2011; 59: 6091-6098

146 Lau CB, Ho TC, Chan TW, Kim SC. Use of dong quai (Angelica sinensis) to treat peri- or postmenopausal symptoms in women with breast cancer: is it appropriate? Menopause 2005; 12: 734-740

147 Rosenberg Zand RS, Jenkins DJ, Diamandis EP. Effects of natural products and nutraceuticals on steroid hormone-regulated gene expression. Clin Chim Acta 2001; 312: 213-219

148 Godecke T, Yao P, Napolitano JG, Nikolic D, Dietz BM, Bolton JL, van Breemen RB, Farnsworth NR, Chen SN, Lankin DC, Pauli GF. Integrated standardization concept for Angelica botanicals using quantitative NMR. Fitoterapia 2012; 83: 18-32

149 Schinkovitz A, Dietz B, Deng S, Chen SN, Pro S, Lankin D, Nikolic D, van Breemen RB, Bolton JL, Farnsworth NR, Pauli GF. The stability of Z-ligustilide and its relevance for the biological evaluation of Angelica botanicals. Planta Med 2007; 73: 817

150 Mahady GB. Is black cohosh estrogenic? Nutr Rev 2003; 61: 183-186

151 Bodinet C, Freudenstein J. Influence of Cimicifuga racemosa on the proliferation of estrogen receptor-positive human breast cancer cells. Breast Cancer Res Treat 2002; 76: 1-10

152 Freudenstein J, Dasenbrock C, Nisslein T. Lack of promotion of estrogendependent mammary gland tumors in vivo by an isopropanolic Cimicifuga racemosa extract. Cancer Res 2002; 62: 3448-3452

153 Gaube F, Wolfl S, Pusch L, Kroll TC, Hamburger M. Gene expression profiling reveals effects of Cimicifuga racemosa (L.) NUTT. (black cohosh) on the estrogen receptor positive human breast cancer cell line MCF-7. BMC Pharmacol 2007; 7: 11

154 Lupu R, Mehmi I, Atlas E, Tsai MS, Pisha E, Oketch-Rabah HA, Nuntanakorn P, Kennelly EJ, Kronenberg F. Black cohosh, a menopausal remedy, does not have estrogenic activity and does not promote breast cancer cell growth. Int J Oncol 2003; 23: 1407-1412
155 Zierau O, Bodinet C, Kolba S, Wulf M, Vollmer G. Antiestrogenic activities of Cimicifuga racemosa extracts. J Steroid Biochem Mol Biol 2002; 80: 125-130

156 Burdette JE, Liu J, Chen SN, Fabricant DS, Piersen CE, Barker EL, Pezzuto $J M$, Mesecar A, Van Breemen RB, Farnsworth NR, Bolton JL. Black cohosh acts as a mixed competitive ligand and partial agonist of the serotonin receptor. J Agric Food Chem 2003; 51: 5661-5670

157 Mercado-Feliciano M, Cora MC, Witt KL, Granville CA, Hejtmancik MR, Fomby L, Knostman KA, Ryan MJ, Newbold R, Smith C, Foster PM, Vallant $M K$, Stout MD. An ethanolic extract of black cohosh causes hematological changes but not estrogenic effects in female rodents. Toxicol Appl Pharmacol 2012; 263: 138-147

158 Seidlova-Wuttke D, Jarry $H$, Wuttke W. Effects of estradiol benzoate, raloxifen and an ethanolic extract of Cimicifuga racemosa in nonclassical estrogen regulated organs of ovariectomized rats. Planta Med 2009; 75: 1279-1285

159 Ruhlen RL, Haubner J, Tracy JK, Zhu W, Ehya H, Lamberson WR, Rottinghaus GE, Sauter ER. Black cohosh does not exert an estrogenic effect on the breast. Nutr Cancer 2007; 59: 269-277

160 Liu Z, Yang Z, Zhu M, Huo J. Estrogenicity of black cohosh (Cimicifuga racemosa) and its effect on estrogen receptor level in human breast cancer MCF-7 cells. Wei Sheng Yan Jiu 2001; 30: 77-80

161 Bolle P, Mastrangelo S, Perrone F, Evandri MG. Estrogen-like effect of a Cimicifuga racemosa extract sub-fraction as assessed by in vivo, ex vivo and in vitro assays. J Steroid Biochem Mol Biol 2007; 107: 262269

162 Kanadys WM, Leszczynska-Gorzelak B, OleszczukJ. Efficacy and safety of Black cohosh (Actaea/Cimicifuga racemosa) in the treatment of vasomotor symptoms - review of clinical trials. Ginekol Pol 2008; 79: 287-296

163 Benghuzzi H, Tucci M, Eckie R, Hughes J. The effects of sustained delivery of diosgenin on the adrenal gland of female rats. Biomed Sci Instrum 2003; 39: 335-340

164 Tucci M, Benghuzzi H. Structural changes in the kidney associated with ovariectomy and diosgenin replacement therapy in adult female rats. Biomed Sci Instrum 2003; 39: 341-346

165 Lu A, Beehner JC, Czekala NM, Koenig A, Larney E, Borries C. Phytochemicals and reproductive function in wild female Phayre's leaf monkeys (Trachypithecus phayrei crepusculus). Horm Behav 2011; 59: 28-36

166 Emery Thompson M, Wilson ML, Gobbo G, Muller MN, Pusey AE. Hyperprogesteronemia in response to Vitex fischeri consumption in wild chimpanzees (Pan troglodytes schweinfurthii). Am J Primatol 2008; 70: 1064-1071

167 Hall E, Frey BN, Soares CN. Non-hormonal treatment strategies for vasomotor symptoms: a critical review. Drugs 2011; 71: 287-304

168 Nadaoka I, Yasue M, Sami M, Kitagawa Y. Oral administration of Cimicifuga racemosa extract affects immobilization stress-induced changes in murine cerebral monoamine metabolism. Biomed Res 2012; 33: 133-137

169 Geller SE, Shulman LP, van Breemen RB, Banuvar S, Zhou Y, Epstein G, Hedayat S, Nikolic D, Krause EC, Piersen CE, Bolton JL, Pauli GF, Farnsworth NR. Safety and efficacy of black cohosh and red clover for the management of vasomotor symptoms: a randomized controlled trial. Menopause 2009; 16: 1156-1166

170 Shams T, Setia MS, Hemmings R, McCusker J, Sewitch M, Ciampi A. Efficacy of black cohosh-containing preparations on menopausal symptoms: a meta-analysis. Altern Ther Health Med 2010; 16: 36-44

171 Toyohira Y, Ueno S, Tsutsui M, Itoh H, Sakai N, Saito N, Takahashi K, Yanagihara $N$. Stimulatory effects of the soy phytoestrogen genistein on noradrenaline transporter and serotonin transporter activity. Mol Nutr Food Res 2010; 54: 516-524

172 Dinh LD, Simmen U, Bueter KB, Bueter B, Lundstrom K, Schaffner W. Interaction of various Piper methysticum cultivars with CNS receptors in vitro. Planta Med 2001; 67: 306-311

173 Ofir R, Tamir S, Khatib S, Vaya J. Inhibition of serotonin re-uptake by licorice constituents. J Mol Neurosci 2003; 20: 135-140

174 Deng S, Chen SN, Yao P, Nikolic D, van Breemen RB, Bolton JL, Fong HH, Farnsworth NR, Pauli GF. Serotonergic activity-guided phytochemical investigation of the roots of Angelica sinensis. J Nat Prod 2006; 69: 536-541

175 Leach MJ, Moore V. Black cohosh (Cimicifuga spp.) for menopausal symptoms. Cochrane Database Syst Rev 2012; DOI: 10.1002/ 14651858.CD14007244 
176 Ross SM. Menopause: a standardized isopropanolic black cohosh extract (remifemin) is found to be safe and effective for menopausal symptoms. Holist Nurs Pract 2012; 26: 58-61

177 Carmignani LO, Pedro AO, Costa-Paiva LH, Pinto-Neto AM. The effect of dietary soy supplementation compared to estrogen and placebo on menopausal symptoms: a randomized controlled trial. Maturitas 2010; 67: 262-269

178 Bolanos R, Del Castillo A, Francia J. Soy isoflavones versus placebo in the treatment of climacteric vasomotor symptoms: systematic review and meta-analysis. Menopause 2010; 17: 660-666

179 Levis S, Strickman-Stein N, Ganjei-Azar P, Xu P, Doerge DR, Krischer J. Soy isoflavones in the prevention of menopausal bone loss and menopausal symptoms: a randomized, double-blind trial. Arch Intern Med 2011; 171: 1363-1369

180 Wulf $\mathrm{H}$. The role of soy isoflavones in menopausal health: report of The North American Menopause Society. Utian Translational Science Symposium in Chicago, IL (October 2010). Menopause 2011; 18: 732-753

181 van de Weijer PH, Barentsen R. Isoflavones from red clover (Promensil) significantly reduce menopausal hot flush symptoms compared with placebo. Maturitas 2002; 42: 187-193

182 Tice JA, Ettinger B, Ensrud K, Wallace R, Blackwell T, Cummings SR. Phytoestrogen supplements for the treatment of hot flashes: the Isoflavone Clover Extract (ICE) Study: a randomized controlled trial. JAMA 2003; 290: 207-214

183 Penotti M, Fabio E, Modena AB, Rinaldi M, Omodei U, Vigano P. Effect of soy-derived isoflavones on hot flushes, endometrial thickness, and the pulsatility index of the uterine and cerebral arteries. Fertil Steril 2003; 79: 1112-1117

184 Upmalis DH, Lobo R, Bradley L, Warren M, Cone FL, Lamia CA. Vasomotor symptom relief by soy isoflavone extract tablets in postmenopausal women: a multicenter, double-blind, randomized, placebo-controlled study. Menopause 2000; 7: 236-242

185 Pfitscher A, Reiter E, Jungbauer A. Receptor binding and transactivation activities of red clover isoflavones and their metabolites. J Steroid Biochem Mol Biol 2008; 112: 87-94

186 Han DH, Denison MS, Tachibana H, Yamada K. Relationship between estrogen receptor-binding and estrogenic activities of environmental estrogens and suppression by flavonoids. Biosci Biotechnol Biochem 2002; 66: 1479-1487

187 Cheng W, Chen L, Yang S, Han J, Zhai D, Ni J, Yu C, Cai Z. Puerarin suppresses proliferation of endometriotic stromal cells partly via the MAPK signaling pathway induced by 17 ss-estradiol-BSA. PLoS One 2012; 7: e45529

188 Milligan SR, Kalita JC, Heyerick A, Rong H, De Cooman L, De Keukeleire D. Identification of a potent phytoestrogen in hops (Humulus lupulus L.) and beer. J Clin Endocrinol Metab 1999; 84: 2249-2252

189 Kupfer R, Swanson L, Chow S, Staub RE, Zhang YL, Cohen I, Christians U. Oxidative in vitro metabolism of liquiritigenin, a bioactive compound isolated from the Chinese herbal selective estrogen beta-receptor agonist MF101. Drug Metab Dispos 2008; 36: 2261-2269

190 Tamir S, Eizenberg M, Somjen D, Izrael S, Vaya J. Estrogen-like activity of glabrene and other constituents isolated from licorice root J Steroid Biochem Mol Biol 2001; 78: 291-298 